\title{
Human amplified changes in precipitation-runoff patterns in large river basins of the Midwestern United States
}

\author{
Sara A. Kelly ${ }^{1}$, Zeinab Takbiri ${ }^{2}$, Patrick Belmont ${ }^{1}$, and Efi Foufoula-Georgiou ${ }^{3}$ \\ ${ }^{1}$ Department of Watershed Sciences, Utah State University, Logan, 84322-5210, USA \\ ${ }^{2}$ Department of Civil, Environmental, and Geo-Engineering, University of Minnesota, Minneapolis, MN 55455-0116, USA \\ ${ }^{3}$ Department of Civil and Environmental Engineering, University of California, Irvine, CA 92697, USA \\ Correspondence to: Sara A. Kelly (sara.kelly@aggiemail.usu.edu)
}

Received: 8 March 2017 - Discussion started: 15 March 2017

Revised: 17 August 2017 - Accepted: 17 August 2017 - Published: 9 October 2017

\begin{abstract}
Complete transformations of land cover from prairie, wetlands, and hardwood forests to row crop agriculture and urban centers are thought to have caused profound changes in hydrology in the Upper Midwestern US since the 1800s. In this study, we investigate four large (23000-69000 $\mathrm{km}^{2}$ ) Midwest river basins that span climate and land use gradients to understand how climate and agricultural drainage have influenced basin hydrology over the last 79 years. We use daily, monthly, and annual flow metrics to document streamflow changes and discuss those changes in the context of precipitation and land use changes. Since 1935, flow, precipitation, artificial drainage extent, and corn and soybean acreage have increased across the region. In extensively drained basins, we observe 2 to 4 fold increases in low flows and 1.5 to 3 fold increases in high and extreme flows. Using a water budget, we determined that the storage term has decreased in intensively drained and cultivated basins by $30-200 \%$ since 1975 , but increased by roughly $30 \%$ in the less agricultural basin. Storage has generally decreased during spring and summer months and increased during fall and winter months in all watersheds. Thus, the loss of storage and enhanced hydrologic connectivity and efficiency imparted by artificial agricultural drainage appear to have amplified the streamflow response to precipitation increases in the Midwest. Future increases in precipitation are likely to further intensify drainage practices and increase streamflows. Increased streamflow has implications for flood risk, channel adjustment, and sediment and nutrient transport and presents unique challenges for agriculture and water resource management in the Midwest. Better documentation of existing and future drain tile and ditch installation is needed to further understand the role of climate versus drainage across multiple spatial and temporal scales.
\end{abstract}

\section{Introduction}

\subsection{Whether humans, climate, or both have caused streamflow change matters for water quality and watershed management}

The magnitude, frequency, duration, and timing of streamflows strongly influence the water quality, sediment and nutrient transport, channel morphology, and habitat conditions of a river channel. While streamflows fluctuate naturally over event to millennial timescales, humans have also altered rainfall-runoff processes in pervasive and profound ways (Vörösmarty et al., 2004). For example, humans have substantially altered the timing and magnitude of evapotranspiration, have dammed, channelized, and leveed waterways, and have installed artificial drainage networks in former wetlands (Boucher et al., 2004; Dumanski et al., 2015; Rockström et al., 2014; Schottler et al., 2014; Vörösmarty et al., 2004). While it is inevitable that wetland removal and artificial drainage will change rainfall-runoff processes, the effects of drainage on the hydrologic cycle may be subtle and difficult to discern, and may manifest differently at different spatial scales and times of year (e.g., Bullock and Acreman, 2003; Foufoula-Georgiou et al., 2016; Irwin and Whiteley, 1983; O'Connell et al., 2007).

Systematic increases in peak, mean, total, and base flows are widely reported in the Midwestern USA. Such increases have been attributed to changes in climate, such as increasing precipitation and earlier snowmelt, and land use, including widespread conversion from perennial vegetation, such as grasses, to annual row crops, primarily corn and soybean, and the addition of artificial drainage (e.g., Foufoula-Georgiou et al., 2015; Frans et al., 2013; Gerbert and Krug, 1996; 
Juckem et al., 2008; Novotny and Stefan, 2007; Schilling and Libra, 2003; Schottler et al., 2014; Xu et al., 2013; Zhang and Schilling, 2006). Furthermore, large-scale, land use land cover (LULC) changes influence surface energy fluxes and thus have feedbacks on climate and water balances. As a result of the Green Revolution, net primary production increased during the twentieth century in the Midwestern US, which subsequently increased evapotranspiration (ET) demands, especially during the peak growing season (Mueller et al., 2015). Corn yields (bushels per acre) tripled in the US between 1949 and 1989 (US Department of Agriculture Bureau of Agricultural Economics Crop Reporting Board, 1949; US Department of Agriculture National Agricultural Statistics Service Agricultural Statistics Board, 1990). However, any increase in ET demand due to crop yield increases may have been offset during this time by the addition and replacement of agricultural drainage. Regional studies have reported increases in Midwestern crop yields and yet simultaneously decreases in ET for artificially drained agricultural basins, where streamflows have subsequently increased during the twentieth century. (Frans et al., 2013; Schottler et al., 2014). Therefore, the question remains: how have combined climate and land use changes affected streamflows in very large $\left(>10^{4} \mathrm{~km}^{2}\right)$ watersheds, the scale at which many states and federal programs are often tasked with monitoring and evaluating water quality?

Many basins across the Midwestern Corn Belt and around the world are experiencing greater runoff, higher sediment and nutrient loads, and accelerated loss of habitat than in the past (Blann et al., 2009). Linkages between artificial agricultural drainage and increased nutrient export have been well documented (David et al., 1997; Goolsby et al., 1999; Kreiling and Houser, 2016; Letey et al., 1977; Randall and Mulla, 2001; Royer et al., 2006; Schilling et al., 2017; Sims et al., 1998). Less research has focused on the implications of hydrologic change for sediment loads in agricultural landscapes. For waters impaired by sediment under the US Clean Water Act (CWA), EU Water Framework Directive, and similar regulations around the world, loads often consist of both natural and human-derived sediment sources (Belmont et al., 2011; Gran et al., 2011; Belmont and Foufoula-Georgiou, 2017). Differentiating between these two sources is often very difficult, and yet is essential for identifying and achieving water quality standards (Belmont et al., 2014; Trimble and Crosson, 2000; Wilcock, 2009). Sediment sources derived from near or within the channel itself (e.g., bank erosion from channel widening) are particularly sensitive to changes in streamflows (Lauer et al., 2017; Schottler et al., 2014; Lenhart et al., 2013). Bank erosion is a significant sediment source in many alluvial rivers, contributing as much as 80 to $96 \%$ of the sediment that comprises a river's total sediment load (Kronvang et al., 2013; Palmer et al., 2014; Schaffrath et al., 2015; Simon et al., 1996; Stout et al., 2014; Willett et al., 2012). For some agricultural basins, erosion of near-channel sources contributes more fine sediment than does agricultural field erosion (Belmont et al., 2011; Lenhart et al., 2012; Trimble, 1999). However, if artificial drainage practices act to amplify streamflows, then the source of accelerated bank erosion may still be linked to agriculture. Artificial drainage is currently unregulated at the federal level in the US and many countries around the world. Therefore, in stark contrast to urban hydrology, progress in understanding the effects of agricultural drainage has been hindered by the fact that accurate data regarding the location, size, depth, efficiency, and connectivity of sub-surface drainage systems are rarely available.

\subsection{Artificial drainage improves agricultural productivity but may amplify streamflows in large watersheds}

The United States is the largest producer of corn and soybeans in the world (Boyd and McNevin, 2015; Guanter et al., 2014). Exceptionally high agricultural productivity over the past century and a half required massive conversion of grasslands, wetlands, and forests to agricultural lands (Dahl, 1990; Dahl and Allord, 1996; Marschner, 1974). Although many advances in cropping practices have led to the modern day prosperity of the Corn Belt, artificial drainage has played a critical role for agriculture in the Midwestern USA. Throughout this paper "artificial drainage" is used as a general term that refers to both human installed surface ditches and subsurface tile drainage. Tile drains and ditch networks are installed to ameliorate water-logged soils, which are known to limit crop growth (Hillel, 1998; Sullivan et al., 2001; Wuebker et al., 2001). Modern tile drains are composed of corrugated plastic tubing and are typically installed at depths of 1-2 $\mathrm{m}$ to control the elevation of the water table below the soil surface (Hillel, 1998).

The economic benefits of artificial drainage are well understood by Midwestern farmers, who have invested heavily in drainage systems to reduce soil moisture, surface overland flow, and soil erosion, and increase land value, ease of equipment operation, and production of first class crops such as corn and soy (Burns, 1954; Fausey et al., 1987; Hewes and Frandson, 1952; Johnston, 2013; McCorvie and Lant, 1993). Installation or enhancement of tile drainage systems often occurs simultaneously with land conversion from wild hay and small grains to soybeans, as Fig. S1 demonstrates in the Supplement (Blann et al., 2009; Burns, 1954; Hewes and Frandson, 1952). Conversion of perennial grasses to corn and soybean rotations does not necessarily lead to a reduction in ET over the course of an entire growing season, at least for well-drained soils (Hamilton et al., 2015). However, several studies report a reduction of ET early in the growing season (Hickman et al., 2010; McIsaac et al., 2010; Schottler et al., 2014; Zeri et al., 2013) and greater evapotranspiration rates than native prairie during the peak growing season (Wolf and Market, 2007; Zeri et al., 2013). Thus changes in land cover (and ET) and drainage expansion have been found to alter 
watershed hydrology and increase mean annual flows (Harrigan et al., 2014; Kibria et al., 2016), base flows (Juckem et al., 2008; Robinson, 1990; Schilling and Libra, 2003; Xu et al., 2013), annual peak flows (Dumanski et al., 2015; Magner et al., 2004; Skaggs et al., 1980, 1994), and total flow volumes (Dumanski et al., 2015; Frans et al., 2013; Lenhart et al., 2011). While it seems inevitable that altering ET and subsurface drainage efficiency should have measurable effects on streamflow, the combined effects have proven difficult to isolate empirically, especially across scales, due to measurement uncertainties, high temporal and spatial variability in antecedent moisture conditions and runoff processes, a shift towards a wetter climate today than in the historical past, as well as limited documentation of artificial drainage installation in the US.

\subsection{Research questions}

In this paper we couple analysis of historical patterns in large $\left(>10^{4} \mathrm{~km}^{2}\right)$ river basin hydrology in the Midwestern USA with historical climate and land use data to identify how each of these factors has influenced streamflow patterns. Specifically, we address the following questions: (1) how have LULC, climate, and streamflows changed during the twentieth and twenty-first centuries; (2) what are the timing, timescales and times of year where changes are most prominent; and (3) can changes in climate alone explain changes in streamflow? We hypothesize that in the most intensively managed agricultural basins, climate alone cannot explain streamflow patterns, and that land use changes in the Midwestern USA have amplified the expected hydrologic change associated with climate. We test this hypothesis in four large river basins with different histories and climates using a suite of quantitative methods that test the statistical significance of changes in streamflow and precipitation at multiple timescales. Finally, we present a water budget for each basin.

We acknowledge that the conversion of precipitation to streamflow occurs by a complex suite of physical processes. Inevitably, we lack temporal and spatial coverage/resolution of all of the relevant hydrologic fluxes (e.g., groundwater, actual evapotranspiration, infiltration, soil water flux rates) to characterize the system completely and have limited ability to ascribe subtle changes to any given physical process, especially at large scales. Yet, with increasing concerns about water quality and aquatic biota, disentangling the effects of artificial drainage and changing precipitation patterns is important for evaluating economic costs, benefits and risks, predicting the effects of future land and water management, and informing future policy.

\section{Study areas: large river basins of the Midwest with varying degrees of climate and land use change}

We analyze hydrologic and land use change in four large Midwestern watersheds during 1935-2013. We selected these basins for the following reasons: all are agricultural, to various degrees, primarily producing corn and soybeans; all are located mainly within the Central Lowland physiographic province and were affected by continental glaciation resulting in mostly flat, poorly drained uplands and incised river valleys (Arnold et al., 1999; Barnes, 1997; Belmont et al., 2011; Day et al., 2013; Gran et al., 2009; Groschen et al., 2000; Rosenberg et al., 2005; Stark et al., 1996); and all are characterized by a humid, temperate climate (Kottek et al., 2006). Additionally, all four basins also contain waters impaired for excessive sediment under the US Clean Water Act. Therefore, deconvolving climate and land use effects on basin hydrology is essential for developing and attaining sediment- and nutrient-related water quality standards. Despite the broad similarities between basins, we have intentionally selected watersheds that span a gradient of climate and land use change. From northwest to southeast, these include the Red River of the North basin (RRB), upstream of Grand Forks, ND $\left(67005 \mathrm{~km}^{2}\right)$, Minnesota River basin (MRB), upstream of Jordan, MN (42 $\left.162 \mathrm{~km}^{2}\right)$, Chippewa River basin (CRB), upstream of Durand, WI $\left(23444 \mathrm{~km}^{2}\right)$, and Illinois River basin (IRB), upstream of Valley City, IL (69 $268 \mathrm{~km}^{2}$ ) (Fig. 1).

Soils in the Minnesota River basin consist of organic rich but poorly drained mollisols with a very small area consisting of alfisols and entisols (Stark et al., 1996). The Illinois River basin is generally dominated mollisols, containing around $1 \%$ organic matter and generally of low to very low permeability, with some presence of more permeable alfisols and entisols (Arnold et al., 1999; Groschen et al., 2000). The dominant soil orders found in the Red River of the North basin include mollisols and alfisols with some areas underlain by entisols and histosols (Stoner et al., 1993). In the Chippewa River basin, alfisols and spodosols are most prevalent, with occasional pockets of entisols, mollisols, and histosols (Hartemink et al., 2012; Soil Survey Staff, NRCS).

There is a broad northwest to southeast precipitation and temperature gradient across the region (Fig. S2). The RRB is the coldest and driest of all four study basins, although the last 2 decades (1990s and 2000s) have been the wettest in historical times. Precipitation records, lake level elevations, and paleoclimate studies indicate that the basin is prone to extreme climate variability (Fritz et al., 2000; Miller and Frink, 1984). Much like the RRB, the adjacent MRB is uniquely situated at a "climatic triple junction" where warm moist air from the Gulf of Mexico, cold dry air from the Arctic, and dry Pacific air dominate at different times of the year and have varied in relative dominance in the past (Dean and Schwalb, 2000; Fritz et al., 2000). Temperature and humidity in the CRB are more strongly influenced by the Great 


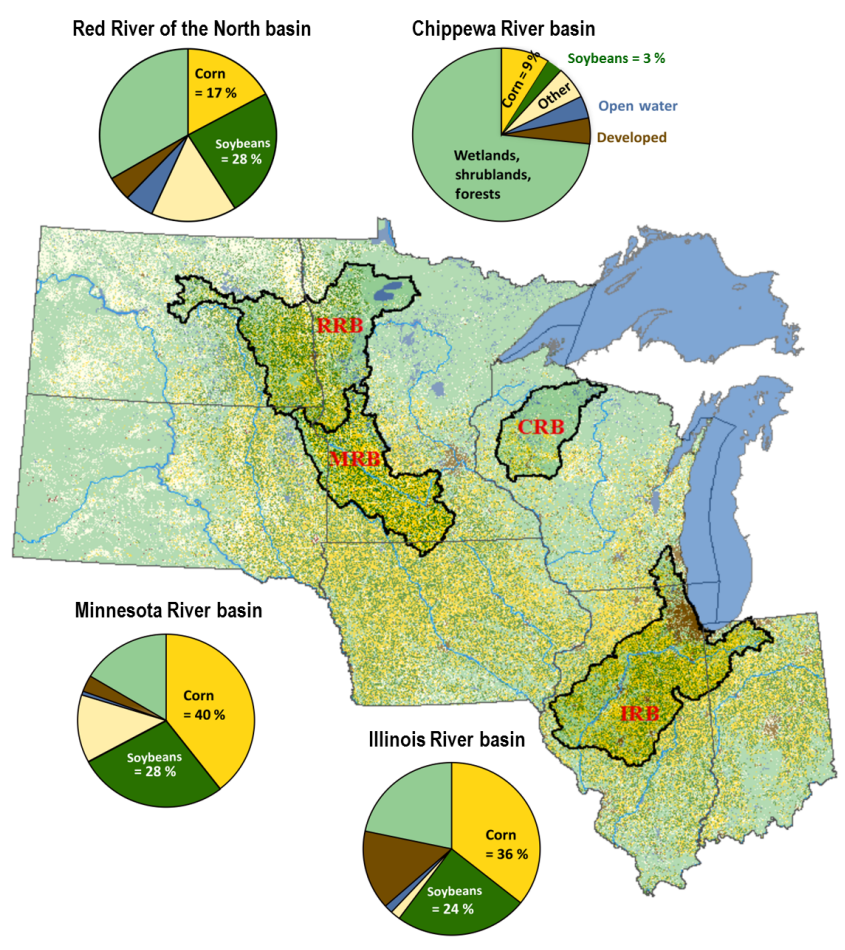

Figure 1. 2013 relative proportion of each land cover class for the four study watersheds, Red River of the North basin (RRB), Minnesota River basin (MRB), Chippewa River basin (CRB), and Illinois River basin (IRB). Data from USDA National Agricultural Statistics Service Cropland Data Layer (2013).

Lakes than in the other basins. The southwest IRB generally receives more precipitation than the northeast in all months. On average each basin from northwest to southeast receives $589,716,822$, and $960 \mathrm{~mm}$ annually, with $59-68 \%$ of the annual precipitation falling in the spring (MAM) and summer (JJA) months based on annual long term means, 19812010 (Fig. S2). Recent increases in precipitation and streamflows have been reported across the region during the last few decades (Foufoula-Georgiou et al., 2015; Frans et al., 2013; Gerbert and Krug, 1996; Groisman et al., 2001; Juckem et al., 2008; Novotny and Stefan, 2007; Schottler et al., 2014).

Settlement, agricultural intensification, and development differ in timing and intensity among basins, but are generally similar. During the early to mid-nineteenth century, permanent occupation of the Midwest was difficult without the aid of artificial drainage (Beauchamp, 1987). Beginning in the mid-1800s, organized drainage districts and enterprises installed ditches and tile to drain many permanently or seasonally wet areas and create more arable land (Beauchamp, 1987; Skaggs et al., 1994). Between 1850 and 1930 Illinois, Minnesota, and Wisconsin lost an estimated 90, 53, and 32\% of state wetlands, respectively (McCorvie and Lant, 1993). Enormous tracts of wetlands and tall grass prairie (millions of acres) were levelled and drained, mainly by surface ditches and canals, in the RRB during this same time (Miller and
Frink, 1984). Artificial drainage increased property value, and as corn and soybean commodity prices increased, as they did following WWII, in the mid-1970s, and most recently a tripling of commodity prices between 2002 and 2012 (Glaser, 2016; Johnston, 2013), lands previously cultivated for small grains or left as wet meadows were drained and converted to soybean and corn fields (Blann et al., 2009; Burns, 1954; Wright and Wimberly, 2013). Although many advances in cropping practices have led to the modern day prosperity of the Corn Belt, drainage installation and intensification has played a critical role for agriculture in the Midwestern US. Today the RRB, MRB, CRB, and IRB, respectively, contain $45,78,12$, and $60 \%$ of land cultivated for corn and soybeans, yet estimates of tile drainage in these basins remain poorly constrained (Fig. 1). Within the Bois de Sioux watershed, a sub-basin of the RRB where permits are required for drain tile installation, annual installation has increased from $5 \mathrm{~km}$ in 1999 to $3096 \mathrm{~km}$ in 2015 for a cumulative total of $24304 \mathrm{~km}$ of new tile installed since 1999 (Bois de Sioux Watershed District, 2015). Tile drainage installation in all basins continues to this day.

The other major anthropogenic impact that affects all basins is dams installed for hydropower, navigation, water resources, and recreation. Most of the dams in our study basins are small and were constructed in the late 1800s and early 1900s (Barnes, 1997; Delong, 2005; Graf, 1999; Hyden, 2010; Lian et al., 2012; Martin, 1965; Stoner et al., 1993; United States Army Corps of Engineers, 2016). Therefore, the effects of these dams would have been established well before our study period. For example, in the Illinois River basin all major dams had been completed by 1939 . Based on work by Lian et al. (2012), streamflow changes post 1938, specifically peak flows, have been influenced more by climate than by dam operations, though they did not consider the effects of drain tile. One exception might be the uppermost Illinois River basin, which has been influenced by expansion of the Chicago metropolitan area. Though historical and present water withdrawals are largely unknown, increased water use for industry, agriculture, and public drinking supply may offset some of the climate impacts of increased precipitation. Urban and suburban detention basins may also limit how much precipitation is converted to runoff. We expect that other water development projects in each basin have minimally affected streamflows at the basin outlet. Conversion of hay and small grains to corn and soybeans accompanied by artificial drainage expansion were likely the largest LULC changes in these basins from the early to midtwentieth century.

\section{Data and methods: LULC, climate, and streamflow}

We explain our methods for addressing how LULC, climate, and streamflows have changed during the twentieth and twenty-first centuries in Sect. 3.1 through 3.3. In Sect. 3.4 
we explain how the timing and timescales of prominent change were determined. We use a water budget to determine whether precipitation and evapotranspiration alone can explain runoff trends in Sect. 3.5.

\subsection{Records of LULC change during the twentieth and twenty-first centuries}

We compiled county level US Census of Agriculture drainage data from 1940, 1950, 1960, 1978, and 2012 for each study watershed, weighing partial counties by area (US Bureau of the Census, 1942, 1952, 1961, 1981; US Department of Agriculture, 2014a). Tabulations of drainage enterprises exclude lands draining less than 500 acres in all years except 1940 (US Bureau of the Census, 1922, 1952). In 1940 and 2012, acres drained by ditches and tile were reported individually. To normalize the land area across basins of different sizes, we report the percentage of watershed area drained. While the uncertainties in these data are high, they are the best data available on a national scale for our study period. Some studies (e.g., David et al., 2010) have taken advantage of other drainage estimates, such as those from Sugg (2007). However, the Sugg (2007) method was calibrated and validated using data from 1987 and 1992 drainage census reports. Therefore it is unclear whether this approach could be used to estimate historical or current drainage extents. Furthermore, the drainage estimates are based on soil type, class, and crop type and assume that state percentages of average cropland area drained are uniform for every county in each state and have remained static through time (Sugg, 2007). Although somewhat tedious, we use US Census of Agriculture drainage data as the best available proxy for the relative drainage extent and expansion through time in each of the four large study basins, the smallest of which is still larger than 20 counties.

County level agricultural census drainage data are only available for 5 census years. Therefore, we also compiled annual USDA National Agricultural Statistics Service (NASS) crop acreage harvested in each basin following the methods of Foufoula-Georgiou et al. (2015). We report the percentage of corn, soybeans, and hay and small grains grown in each watershed from 1915 to 2015. Artificial drainage installation has typically coincided with the replacement of hay and small grains for soybeans as shown in Fig. S1 in the Supplement (Burns, 1954; Hewes and Frandson, 1952). Therefore we use these annual crop data as another indication of LULC changes.

\subsection{Climate records: precipitation and evapotranspiration}

Monthly Parameter elevation Regression on Independent Slopes Model (PRISM) precipitation rasters produced by the PRISM Climate Group (2004) and modeled actual evapotranspiration $\left(\mathrm{ET}_{\mathrm{a}}\right)$ produced by Livneh et al. (2013) are readily available, reproducible, and defensible climatology data that provide continuous spatial and temporal coverage of our study areas. We compiled spatially averaged monthly and annual precipitation and evapotranspiration depths for each watershed for 1935-2013 and 1935-2011, respectively.

Livneh et al. (2013) evapotranspiration was produced for the continental United States using the Variable Infiltration Capacity (VIC) model run at $3 \mathrm{~h}$ time steps in energy balance mode, consistent with methods of Maurer et al. (2002). Hereafter we refer to Livneh et al. (2013) and Maurer et al. (2002) as L13 and M02. We have chosen L13 data over other available estimates of evapotranspiration because they cover a large spatial and temporal domain necessary for the study, i.e., the contiguous US from 1915 to 2011, at reasonable spatial $\left(1 / 16^{\circ}\right)$ and temporal (monthly) resolution, unlike other global and North American reanalysis products such as ERAInterim (data available from 1979 to 2013 at $0.7^{\circ}$ ) and NARR (data available from 1979 to 2015 at $0.3^{\circ}$ ).

Although the precipitation input used to generate the $\mathrm{ET}_{\mathrm{a}}$ data was gridded NCDC COOP station data, Livneh et al. (2013) scaled monthly gridded precipitation to match the PRISM long term mean (1961-1990). We directly compared monthly precipitation from L13 and PRISM (1935-2011) and found that for each of the four study basins the mean error was $1 \%$ (Fig. S3). Further discussion of potential biases in using the $\mathrm{ET}_{\mathrm{a}}$ estimates from L13 is found in the Supplement.

\subsection{Streamflow gauge records}

We evaluated annual (seasonal), monthly, and daily flow metrics for each of the four river basins. Using multiple gauges for a single basin, we compiled seven annual flow metrics: mean annual flow, 7-day average annual low flow winter (November-April), 7-day average annual low flow summer (May-October), peak mean daily flow spring (March-May), peak mean daily flow summer and fall (June-November), high flow days, and extreme flow days using mean daily flow data from USGS gauges within each basin (Fig. S2; Table 1) following the methods of Novotny and Stefan (2007). The number of high and extreme flow days refers to the number of days in a given year that are 1 and 2 standard deviations above the 1950-2010 mean. For each gauge, we normalized the annual flow metric by the 1950-2010 mean to facilitate comparisons among basins and to observe similarities in trends among metrics. Each gauge record included a minimum of 62 years, and of the 63 gauges analyzed, 53 gauges had continuous records. Of the 10 non-continuous records, 4 , $2,2,1$, and 1 gauges were missing for 2, 4, 6, 8, and 14 years of data, respectively, during the period 1929-2013 (Table 1).

For the downstream outlet gauge in each basin (Table 1) we computed annual and monthly streamflow average depths (cm month $\left.{ }^{-1}\right)$ and volumes $\left(\mathrm{km}^{3} \mathrm{month}^{-1}\right)$ for 1935-2013 for the MRB, RRB, and CRB, and 1939-2013 for the IRB due to missing gauge data prior to 1939 . We also calculated 
Table 1. United States Geological Survey (USGS) stream gauge stations listed by study basin.

\begin{tabular}{|c|c|c|c|c|}
\hline USGS gauge station & Station name & Period of record & Length (years) & Notes \\
\hline \multicolumn{5}{|c|}{ Chippewa River basin (9 gauges) } \\
\hline 05356000 & Chippewa River at Bishops Bridge, near Winter, WI & 1929-2013 & 85 & Mainstem river \\
\hline 05356500 & Chippewa River near Bruce, WI & 1929-2013 & 85 & Mainstem river \\
\hline 05360500 & Flambeau River near Bruce, WI & 1952-2013 & 62 & \\
\hline 05362000 & Jump River at Sheldon, WI & 1929-2013 & 85 & \\
\hline 05365500 & Chippewa River at Chippewa Falls, WI & 1929-2013 & 81 & Missing data: $1983-1986$ \\
\hline 05369000 & Red Cedar River at Menomine, WI & 1929-2013 & 85 & \\
\hline 05368000 & Hay River at Wheeler, WI & 1951-2013 & 63 & \\
\hline 05370000 & Eau Galle River at Spring Valley, WI & 1945-2013 & 69 & \\
\hline 05369500 & Chippewa River at Durand, WI & 1929-2013 & 85 & Mainstem river - downstream gauge \\
\hline \multicolumn{5}{|c|}{ Illinois River basin (20 gauges) } \\
\hline 05552500 & Fox River at Dayton, IL & 1929-2013 & 85 & \\
\hline 05543500 & Illinois River at Marseilles, IL & 1929-2013 & 85 & Mainstem river \\
\hline 05555300 & Vermilion River near Leonore, IL & 1932-2013 & 82 & a \\
\hline 05556500 & Big Bureau Creek at Princeton, IL & $1937-2013$ & 77 & a \\
\hline 05554500 & Vermilion River at Pontiac, IL & 1943-2013 & 71 & a \\
\hline 05569500 & Spoon River at London Mills, IL & 1943-2013 & 71 & \\
\hline 05567500 & Mackinaw River near Congerville, IL & 1945-2013 & 69 & a \\
\hline 05568500 & Illinois River at Kingston Mines, IL & 1940-2013 & 74 & Mainstem river \\
\hline 05570000 & Spoon River at Seville, IL & 1929-2013 & 85 & \\
\hline 05584500 & La Moine River at Colmar, IL & $1945-2013$ & 69 & \\
\hline 05585000 & La Moine River at Ripley, IL & 1929-2013 & 85 & \\
\hline 05583000 & Sangamon River Near Oakford, IL & 1929-2013 & 79 & Missing data: $1934-1939$ \\
\hline 05582000 & Salt Creek near Greenview, IL & 1942-2013 & 72 & \\
\hline 05580000 & Kickapoo Creek at Waynesville, IL & $1948-2013$ & 66 & ab \\
\hline 05578500 & Salt Creek near Rowell, IL & 1943-2013 & 71 & \\
\hline 05572000 & Sangamon River at Monticello, IL & 1929-2013 & 85 & a \\
\hline 05576000 & South Fork Sangamon River near Rochester, IL & 1950-2013 & 64 & \\
\hline 05577500 & Spring Creek at Springfield, IL & 1949-2013 & 65 & a \\
\hline 05586100 & Illinois River at Valley City, IL & 1939-2013 & 75 & Mainstem river - downstream gauge \\
\hline 05587000 & Macoupin Creek near Kane, IL & 1929-2013 & 77 & Missing data: $1933-1940$ \\
\hline \multicolumn{5}{|c|}{ Minnesota River basin (12 gauges) } \\
\hline 05291000 & Whetstone River near Big Stone City, SD & 1932-2013 & 82 & \\
\hline 05292000 & Minnesota River at Ortonville, MN & 1939-2013 & 75 & Mainstem river \\
\hline 05304500 & Chippewa River near Milan, MN & 1938-2013 & 76 & \\
\hline 05311000 & Minnesota River at Montevideo, MN & 1930-2013 & 84 & Mainstem river \\
\hline 05313500 & Yellow Medicine River near Granite Falls, MN & 1940-2013 & 74 & \\
\hline 05315000 & Redwood River near Marshall, MN & 1941-2013 & 73 & \\
\hline 05316500 & Redwood River near Redwood Falls, MN & 1936-2013 & 78 & \\
\hline 05317000 & Cottonwood River near New Ulm, MN & 1939-2013 & 75 & \\
\hline 05320000 & Blue Earth River near Rapidan, MN & 1950-2013 & 64 & \\
\hline 05320500 & Le Sueur River near Rapidan, MN & 1950-2013 & 64 & \\
\hline 05325000 & Minnesota River at Mankato, MN & 1930-2013 & 84 & Mainstem river \\
\hline 05330000 & Minnesota River near Jordan, MN & 1935-2013 & 79 & Mainstem river - downstream gauge \\
\hline \multicolumn{5}{|c|}{ Red River of the North basin (22 gauges) } \\
\hline 05050000 & Bois de Sioux River near White Rock, SD & 1942-2013 & 72 & \\
\hline 05046000 & Otter Tail River near Fergus Falls, MN & $1931-2013$ & 83 & \\
\hline 05051500 & Red River of the North at Wahpeton, ND & 1944-2013 & 70 & Mainstem river \\
\hline 05053000 & Wild Rice River near Abercrombie, ND & 1933-2013 & 81 & \\
\hline 05056000 & Sheyenne River near Warwick, ND & 1950-2013 & 64 & \\
\hline 05057000 & Sheyenne River near Cooperstown, ND & 1945-2013 & 69 & \\
\hline 05058000 & Sheyenne River below Baldhill Dam, ND & 1950-2013 & 64 & \\
\hline 05059000 & Sheyenne River near Kindred, ND & 1950-2013 & 64 & \\
\hline 05059500 & Sheyenne River at West Fargo, ND & 1930-2013 & 84 & \\
\hline 05054000 & Red River of the North at Fargo, ND & 1929-2013 & 85 & Mainstem river \\
\hline 05060500 & Rush River at Amenia, ND & $1947-2013$ & 67 & \\
\hline 05062000 & Buffalo River near Dilworth, MN & 1932-2013 & 82 & \\
\hline 05066500 & Goose River at Hillsboro, ND & 1935-2013 & 79 & \\
\hline 05064000 & Wild Rice River at Hendrum, MN & 1945-2013 & 67 & Missing data: $1984-1985$ \\
\hline 05069000 & Sand Hill River at Climax, MN & $1947-2013$ & 65 & Missing data: $1984-1985$ \\
\hline 05074500 & Red Lake River near Red Lake, MN & 1934-2013 & 74 & Missing data: 1994-1999 \\
\hline 05075000 & Red Lake River at High Landing near Goodridge, MN & 1930-1999 & 70 & Missing data: $2000-2013$ \\
\hline 05076000 & Thief River near Thief River Falls, MN & 1929-2013 & 83 & Missing data: $1981-1982$ \\
\hline 05078000 & Clearwater River at Plummer, MN & 1940-2013 & 70 & Missing data: $1979-1982$ \\
\hline 05078500 & Clearwater River at Red Lake Falls, MN & 1935-2013 & 77 & Missing data: $1981-1982$ \\
\hline 05079000 & Red Lake River at Crookston, MN & $1929-2013$ & 85 & \\
\hline 05082500 & Red River of the North at Grand Forks, ND & $1929-2013$ & 85 & Mainstem river - downstream gauge \\
\hline
\end{tabular}

a Tributary gauges, predominantly agricultural, not influenced by major dams.

b Mean annual flow and 7-day low-flow winter 1949-2013. 
daily streamflow change exceedance probabilities, where $\mathrm{d} Q / \mathrm{d} t>0$ characterizes the rising limbs of daily hydrographs and $\mathrm{d} Q / \mathrm{d} t<0$ the falling limbs.

\subsection{Determining the timing and timescales of prominent LULC, climate, and runoff changes}

In order to determine whether observed changes in climate and streamflow are statistically meaningful and potentially coincident with LULC change, we first determined the timing of climate, streamflow, and LULC change. Annual crop data reveal the timing of a rapid expansion of soybean acreage and indicate land use land cover transitions (LCTs) when soybean acreage exceeds hay and small grains (Foufoula-Georgiou et al., 2015). We identified the timing of precipitation and streamflow change using wavelets and by fitting a piecewise linear regression (PwLR) using a leastsquares approach to the monthly streamflow and precipitation volume time series in each basin (Liu et al., 2010; Tomé and Miranda, 2004; Verbesselt et al., 2010; Zeileis et al., 2003).

A common method for detecting and quantifying changes in the magnitude/frequency content of a time series is via a localized time-frequency analysis using wavelets. The continuous wavelet transform (CWT) of a signal $x(t)$ is defined as the convolution of the signal with scaled and translated versions of a mother wavelet $\psi(t)$ :

$T(a, b)=\frac{1}{\sqrt{a}} \int_{-\infty}^{+\infty} x(t) \psi^{*}\left(\frac{t-b}{a}\right) \mathrm{d} t$,

where $\psi\left(\frac{t-b}{a}\right)$ is the mother wavelet scaled by parameter $a$ and translated by parameter $b$, and ${ }^{*}$ denotes the complex conjugate. By changing $a$ and $b$ the CWT quantifies the localized energy or variance of a signal at different times and scales (frequencies). To every scale there is a corresponding frequency assigned as the central frequency of the Fourier transform of the wavelet at that scale. This relationship is analytically computable depending on the chosen mother wavelet. In this paper, we use the Morlet wavelet (Addison, 2002; Daubechies, 1992; Seuront and Strutton, 2003), which has been proven effective for analyzing climate signals such as El Niño, streamflow, and precipitation among others (e.g., Anctil and Coulibaly, 2004; Foufoula-Georgiou et al., 2015; Labat et al., 2001; Torrence and Compo, 1998, and the references therein). The Morlet wavelet is simply a complex wave within a Gaussian envelope, and by choosing the central frequency $f_{0}$ appropriately, it simplifies to the form

$\psi(t)=\frac{1}{\pi^{1 / 4}} e^{i 2 \pi f_{0} t} e^{-t^{2} / 2}$

Here we used $f_{0}=0.849$ as this achieves the best timefrequency localization (Addison, 2002).

We also evaluated precipitation and streamflow change using two statistical tests and three breakpoints. We se- lected 1974/1975 as a breakpoint for the pre-period and postperiod because it lumps the time series data into two roughly equal periods (40/39 years) and coincides with the timing of widespread acceptance of cheaper and easier to install corrugated plastic tile (Fouss and Reeve, 1987), and other studies in the MRB and IRB have identified hydrologic change occurring around that time (e.g., Foufoula-Georgiou et al., 2015; Lian et al., 2012; Schottler et al., 2014). Acknowledging that 1974/1975 may not be the hydrologically relevant breakpoint in all basins at this large scale, we ran statistical tests using 1974/1975 as well as the breakpoints identified for each basin from the PwLR and LCT.

We performed one-tailed Student's $t$ tests or Wilcoxon rank sum tests when data did not meet parametric assumptions after testing log, square root, and arcsine transformations, and Kolmogorov-Smirnov (KS) tests using the R statistical program to analyze changes in the mean and distribution of annual and monthly total flows $(Q)$ at the basin outlet and spatially averaged basin precipitation $(P)$ volumes between each pre-period and post-period (R Core Team, 2013). We test the hypothesis that mean monthly water volumes have increased and their distributions have shifted right during the post-period. We selected an alpha value of 0.05 (95\% confidence level) for all statistical tests performed. Thus we performed $312 t$ tests and $312 \mathrm{KS}$ tests using the annual and monthly $P$ and $Q$ data for each basin, as well as $28 t$ tests on the seven streamflow metrics described in Sect 3.3 for a total of 652 statistical tests. In general the results of the statistical tests are not sensitive to the timing of different breakpoints, spanning nearly 4 decades, and therefore we generally report statistical results for the pre-period (1935-1974) and postperiod (1975-2013), though all results are presented in Table $\mathrm{S} 1$ in the Supplement.

\subsection{Determining the role of climate versus LULC change in streamflows using a water budget}

For a given watershed over a specified time period of integration, water inputs minus water outputs are equal to the change in storage per unit time:

$P-\mathrm{ET}-Q=\frac{\mathrm{d} S}{\mathrm{~d} t}$,

where $P$ is average watershed precipitation $\left(\mathrm{cm} \mathrm{month}{ }^{-1}\right)$, ET is estimated average watershed actual evapotranspiration $\left(\mathrm{cm} \mathrm{month}^{-1}\right), Q$ is runoff depth at the basin outlet $\left(\mathrm{cm}\right.$ month $\left.^{-1}\right)$, and $\frac{\mathrm{d} S}{\mathrm{~d} t}$ is the depth of change in soil water, groundwater, and lake/reservoir storage per unit time.

We have computed average annual water budgets for each basin by accumulating monthly $P$, ET, and $Q$ during the preperiod and post-period determined by the land cover transition (LCT) and 1974/1975 in each basin, to solve for the change in storage. If the change in storage term increases from the pre-period to post-period, we conclude that soil moisture, groundwater, and/or lake/reservoir storage have 
also increased and that climate likely explains most of the increase in $Q$. However, if the change in storage term decreases from the pre-period to post-period, then we conclude that soil moisture, groundwater, and/or lake/reservoir storage have decreased despite precipitation increases, indicating that widespread LULC change has altered watershed storage and contributed, in addition to precipitation, to increased streamflows.

Livneh et al. (2013) did not incorporate land use land cover changes, such as tile drainage expansion or crop changes, into the VIC model. The fact that LULC change is not included in the model is what allows us to test, external to the ET predictions, whether or not a LULC effect exists. There is no evidence of regional groundwater change and the effects of dams and urbanization on streamflows are likely minimal as discussed in Sect. 2. Comparing these data to other estimates of evapotranspiration including four AmeriFlux towers, two of which are in corn-soy agricultural areas, we demonstrate that they are sufficiently reliable modern estimates for our purposes (Table 2; Figs. S4 and S5).

We acknowledge that there is uncertainty in all of the input data and understand that the magnitude of the storage term is sensitive to estimates of ET. Livneh et al. (2013) reported a $17 \%$ overestimation of $\mathrm{ET}_{\mathrm{a}}$ during the summer months when compared with AmeriFlux station data. It is during summer months that ET is most likely limited by soil water availability. Therefore, in addition to the raw water budgets, we present water budgets where we have reduced monthly $\mathrm{ET}_{\mathrm{a}}$ by $17 \%$ during summer months (JJA). This lower estimate of ET effectively reduces the potential amount of streamflow change that could be attributed to land use and artificial drainage and is therefore a more conservative analysis. Overall, the data from Livneh et al. (2013) used in computing the monthly water budgets are consistent with other sources (Bryan et al., 2015; Diak et al., 1998) and provide reasonable modern estimates of $\mathrm{ET}_{\mathrm{a}}$, especially when reducing summer (JJA) $\mathrm{ET}_{\mathrm{a}}$ by $17 \%$ (Figs. S4 and S5).

\section{Results and discussion}

We present records of land use land cover in Sect. 4.1 and discuss the timing of notable change in Sect. 4.2. In Sect. 4.2 we also present the timing, timescales and times of year when changes in precipitation, evapotranspiration, and streamflow magnitude are most prominent. Finally, we present the results of a water budget in Sect. 4.3 to address whether change in climate variables alone can explain runoff trends. Discussion of how the combined results address our three research questions can be found in Sect. 5 .

\subsection{Drainage, corn, and soybean expansion during the twentieth and twenty-first centuries in the Upper Midwest}

Across the Upper Midwest, the percent of land drained by tiles and ditches and cultivated for corn and soybeans has increased since the early twentieth century, while land cultivated for hay and small grains has declined. Figure 2 shows the percent of each watershed drained by tiles and ditches from the Census of Agriculture data, as well as the percent of each county drained by tile in 1940 and 2012. Total drainage and tile drainage have increased in the MRB and IRB, while they remained relatively unchanged from 1940 to 2012 in the CRB and RRB (Fig. 2). The drainage census data show that the MRB has the greatest percentage of the watershed area drained by tile, $19 \%$ in 1940 and $35 \%$ in 2012, and ditches, $7 \%$ in 1940 and $10 \%$ in 2012, followed closely by the IRB (Fig. 2). The Red River of the North basin has experienced very little increase in total drainage since 1940. Most artificial drainage in the RRB is ditches rather than tile drains. Although a dramatic increase in tile installation has been reported in the Red River Valley since the 1990s, the area of this expansion appears small relative to the watershed area. Acres reported to be drained by tile in 2012 represent only $2 \%$ of the total watershed area. The CRB has very little agricultural land and thus the 2012 census reports less than $1.5 \%$ of the watershed area drained by tile and ditches (Fig. 2).

The 1978 census data illustrate the uncertainty associated with reporting, as it is unlikely for total drainage to have decreased between 1960 and 1978 in the RRB and MRB (Fig. 2). Most county ditches and tile in Blue Earth County, Minnesota, were installed during the 1910s and 1920s, with a noticeable drop off during WWII and a resurgence of drainage enterprises starting in the 1960s (Blue Earth County Minnesota, 2016). Burns (1954) reported that the 1940 census data underestimated drainage enterprises in Blue Earth County by $8.5 \%$, simply due to inaccuracies in reporting. According to one report, it was estimated that $27 \%$ of drained land in the United States was not included in the 1960 drainage census due to private drainage operations on lands of less than 500 acres (Gain, 1967). Furthermore, $82,80,51$, and $91 \%$ of all farms in Minnesota, Illinois, North Dakota, and Wisconsin, respectively, were less than 500 acres in 2012, and therefore were not included in survey results (US Department of Agriculture, 2014b). Therefore these estimates are likely to underestimate the area drained by tile and ditches. Although the 2012 census attempts to correct for incomplete and missing responses, because drainage enterprise records have traditionally been so poorly documented, it is difficult to know how much reported acreage underestimates the actual acreage.

We also note that acres drained by tile and ditches do not directly translate to effectiveness of artificial drainage. Several factors influence the flow rate from soils, including the hydraulic conductivity of the soil, macropores, depth of the 
Table 2. Site details for AmeriFlux sites used for comparison with Livneh et al. (2013) evapotranspiration data (L13), where L13(JJA) represents a $17 \%$ reduction in ET during the summer months June, July, and August. The average annual difference is positive when L13/L13(JJA) ET is greater than Ameriflux ET and negative when less. The nearest study watersheds are abbreviated: Chippewa River basin (CRB), Illinois River basin (IRB), Minnesota River basin (MRB), and Red River of the North basin (RRB).

\begin{tabular}{lllll}
\hline Site name & Willow Creek, WI & Bondville, IL & Rosemount, MN & Brookings, SD \\
\hline AmeriFlux site no. & US-WCr & US-Bo1 & US-Ro1 & US-Bkg \\
Latitude & 45.8059 & 40.0062 & 44.7143 & 44.3453 \\
Longitude & -90.0799 & -88.2904 & -93.0898 & -96.8362 \\
Nearest watershed (s) & CRB & IRB & MRB (CRB) & MRB (RRB) \\
Distance to nearest watershed (km) & 0.463 & 13.049 & $43.807(74.169)$ & $25.949(129.688)$ \\
Years & $1999-2002$ & $2003-2008$ & $2004-2009$ & $2004-2009$ \\
Vegetation & Deciduous broadleaf forest & Croplands & Croplands & Grasslands \\
Average difference L13-Ameriflux & $+31 \%$ & $+17 \%$ & $+14 \%$ & $-29 \%$ \\
Average difference L13(JJA)-Ameriflux & $+19 \%$ & $+7 \%$ & $+5 \%$ & $-34 \%$ \\
\hline
\end{tabular}
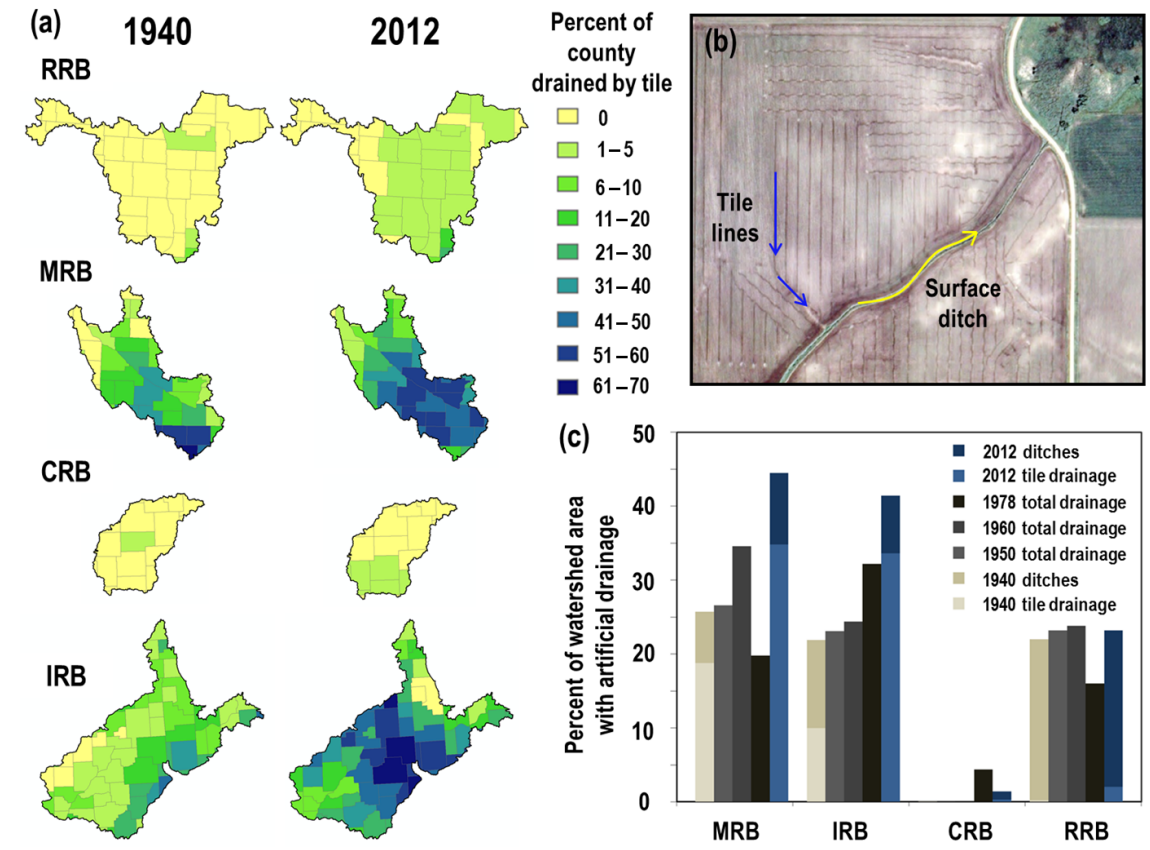

Figure 2. (a) Spatial distribution of tile drainage patterns in 1940 and 2012 for each of the four study basins: Red River of the North basin (RRB), Minnesota River basin (MRB), Chippewa River basin (CRB), and Illinois River basin (IRB). (b) Image showing an example field pattern that combines subsurface tile lines with a surface ditch. (c) Percentage of the total watershed area with artificial drainage from 1940, 1950, 1960, 1978, and 2012 drainage census data. The magnitude of each bar indicates total drainage (ditches and tiles), and 1940 and 2012 bars are broken proportionally into drainage by ditches and tiles.

water table, depths of the tile lines, tile diameter, slope of the tile or ditch, horizontal spacing, as well as precipitation intensity and duration and antecedent soil conditions (Hillel, 1998). We simply do not have this level of information regarding artificial drainage in the Midwestern USA and suspect that the spatial variability in drainage management practices may be high. For example, Naz et al. (2009) mapped tile drains in a $202 \mathrm{~km}^{2}$ Indiana watershed and found tile spacing that ranged from 17 to $80 \mathrm{~m}$.

While we expect that the drainage trends observed are relatively correct, we are cautious about drawing any definitive conclusions from the Census of Agriculture data regarding the actual extent of tile drainage and changes over time. It is clear that these estimates tend to underestimate the amount of drainage. Nevertheless, total drainage and tile drainage in the Minnesota River basin and Illinois River basin have increased considerably since 1940. It is known anecdotally, but is not included in these data, that tile drainage spacing has decreased and intensity or drainage rate in $\mathrm{mm} \mathrm{h}^{-1}$ has increased on agricultural lands, often by a factor of 2 , as was done at the Lamberton Research Station, MN (L. Klossner, personal communication, 17 November 2015). 

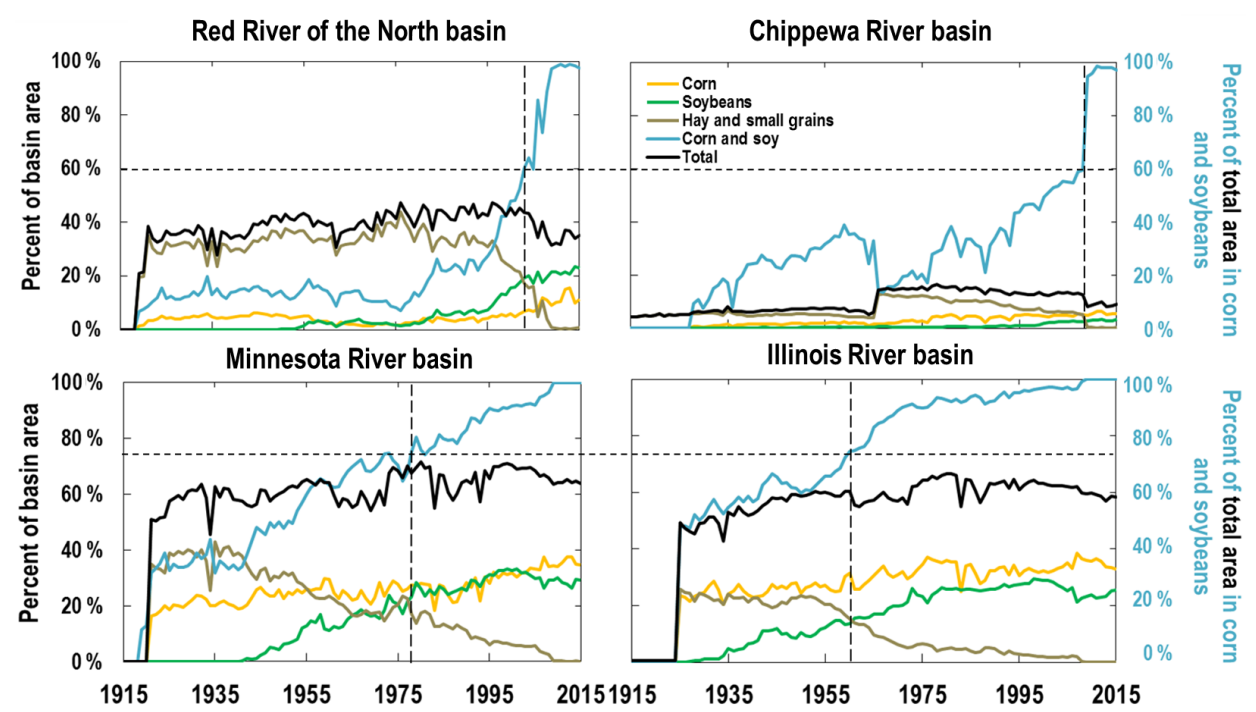

Figure 3. Acres harvested of corn, soybeans, and hay and small grains (barley, oats, wheat) expressed as percent watershed area for each of the basins based on county level data from USDA NASS. The sum of these three commodity groups is shown as a total in black and the percent of this total area in corn and soybeans is plotted in blue. Vertical dashed lines indicate when the percent of basin area harvested for soybeans exceeds hay and small grains. Horizontal dashed lines indicate when the percent of total area harvested for corn and soybeans exceeds $60 \%$ in the Red River of the North basin and Chippewa River basin and $75 \%$ in the Minnesota River basin and Illinois River basin.

Conversion from small grains to soybeans is often accompanied by increased sub-surface drainage installation (Foufoula-Georgoiu et al., 2015). Figure 3 displays the percent of each basin harvested for corn, soybean, and hay and small grains from 1915 to 2015 . There has been a decline in hay and small grains and an increase in soybeans in all four of the watersheds over the period of record. The RRB is the only basin containing a significantly higher percentage of soybean acreage relative to corn; on average since 1995, soybean acreage in the RRB has been more than twice that of corn.

Overall, changes in crop type occurred gradually in the MRB and IRB, and much more rapidly and recently in the RRB (Fig. 3). The CRB is largely non-agricultural: only $9 \%$ of the basin grew corn, soy, and hay and small grains in 2015, and the changes in the basin have been small during the period of record (Fig. 3). While we cannot directly ascribe these changes in crop type to changes in drainage practices or vice versa, they provide a relatively detailed history of LULC and whether the changes occurred gradually or rapidly and recently or long ago in each basin.

\subsection{Timing and magnitude of precipitation, evapotranspiration, and streamflow changes}

\subsubsection{Timing of streamflow change coincides more closely with precipitation change than LULC change}

The land cover transition (LCT), precipitation, and streamflow breakpoints of change identified using piecewise lin- ear regression (PwLR) and continuous wavelet transform (CWT) reveal that the timing of precipitation and streamflow change generally preceded LCT change (Table 3 ). This was true for all tests in the RRB and CRB. However, there are some chronological differences in the order of precipitation, streamflow, and LCT breakpoints. In the IRB, the timing of LCT precedes precipitation and streamflow breakpoints identified using PwLR and CWT by between 13 and 20 years (Table 3). In the MRB, LCT follows precipitation by 20 years and streamflow by 11 years as identified using PwLR, but precedes the streamflow breakpoint by 1 year identified using CWT (Table 3).

Land cover transition breakpoints shown in Fig. 3 are not exact; land cover change occurs gradually, and therefore LCT breakpoints represent when a large portion of each watershed was converted from hay and small grains to soybeans. Land cover transition breakpoints are indicated in two ways: (1) when the percent watershed area harvested for soybeans exceeds hay and small grains, and (2) when the proportion of the total acreage harvested for the three commodity groups is dominated by corn and soybeans. The second criterion varies from basin to basin, as some basins may have historically grown more hay and small grains, and others more corn and soybeans. In the CRB and RRB, hay and small grains exceeded $50 \%$ of the total area harvested for corn, soybeans, and hay and small grains from 1915 until the year 2000 or later. However, in the MRB and IRB, hay and small grains only exceeded $50 \%$ of the total area harvested for the three commodity groups from 1915 until 1950 or earlier. The LCT breakpoints, indicated by the vertical dashed lines in 
Table 3. Summary of the breakpoint years identified from land cover transition (LCT) (Fig. 3), piecewise linear regression (PwLR) of precipitation $(P)$ and streamflow $(Q)$, and continuous wavelet transform (CWT) of $P$ and $Q$ (Fig. 4).

\begin{tabular}{lrrrrr}
\hline & LCT (Fig. 3) & $P$ (PwLR) & $Q$ (PwLR) & $P$ (CWT, Fig. 4) & $Q$ (CWT, Fig. 4) \\
\hline Red River of the North basin & $2003 / 2004$ & $1987 / 1988$ & $1989 / 1990$ & No change & 1995 \\
Minnesota River basin & $1978 / 1979$ & $1958 / 1959$ & $1967 / 1968$ & No change & 1980 \\
Illinois River basin & $1961 / 1962$ & $1981 / 1982$ & $1981 / 1982$ & No change & 1975 \\
Chippewa River basin & $2009 / 2010$ & $1995 / 1996$ & $1995 / 1996$ & No change & No change \\
\hline
\end{tabular}

Fig. 3, approximately coincide with the horizontal dashed lines, which represent a time when the percent of the total acres harvested for the three commodity groups exceeded $60 \%$ in the RRB and CRB, where hay and small grains have historically dominated, and $75 \%$ in the MRB and IRB, where corn and soybeans have historically dominated. We acknowledge that these breakpoints do not consider the actual extent of soybeans, which is assumed to be a surrogate approximation for the area of drained croplands. Soybean coverage is much higher for both the MRB and IRB compared to the RRB and CRB, even before 1955. Considering the large proportion of the MRB and IRB watersheds cultivated for soybeans in the early 1950s combined with extensive (20-25\%) drainage by 1940 and 1950 (Fig. 2), this suggests streamflow changes generally occurred after both precipitation and LCT changes.

We observe minimal changes in the energy of the annual and inter-annual precipitation signal for any basins during the period of record, and therefore could not identify the timing of precipitation change in any basin using CWT (Fig. 4). However, Fig. 4 displays significant increases in the annual and inter-annual energy of the basin outlet streamflow signal around 1975, 1980, and 1995 for the IRB, MRB, and RRB, respectively, while the CRB does not exhibit any striking changes in energy throughout the period of record. All decadal energy shifts in the precipitation signals are clearly translated into the decadal energy of the streamflow signals for all four basins (Fig. 4). The observed correlation between the decadal energy changes in streamflow and precipitation signals together with the lack of any significant correlation between their energies at the annual scale may signal the importance of factors other than precipitation, here artificial drainage, to streamflows in the MRB, RRB, and IRB at the annual scale.

In all basins, the timing of precipitation change coincided with or preceded streamflow breakpoints based on PwLR (Table 3). Similar temporal coincidence of precipitation and streamflow breakpoints in contrast to the LCT and streamflow breakpoints may suggest that streamflow changes are tightly coupled with precipitation changes. However, that interpretation fails to account for the potential effects of drainage, which could amplify the streamflow response to precipitation.

\subsubsection{Seasonal- and annual-scale changes in precipitation, evapotranspiration, and streamflow}

The raw time series of spatially averaged annual precipitation and streamflow depths $(\mathrm{cm})$, reported in the Supplement, show an increasing trend in precipitation and streamflow in the RRB, MRB, and IRB and no trend in the CRB (Fig. S6). The magnitude of the precipitation and streamflow trends are on the order of $120-150$ and $90-170$ mm century $^{-1}$, respectively, and are consistent with those reported for the entire Upper Mississippi River basin by Frans et al. (2013). Xu et al. (2013) report precipitation trends that are similar to our study and Frans et al. (2013) in $22 \%$ of the study watersheds (average size $489 \mathrm{~km}^{2}$ ) in Iowa, Illinois, Indiana, and Ohio. Figure 5a shows 5-year running averages of seven annual streamflow metrics, where normalized values of 1 indicate that the annual value is equivalent to the mean (19502010) value. Stationary flow statistics vary around 1 for the entire time series, as is the case for the Chippewa River basin (Fig. 5). Non-stationary time series systematically deviate from 1, indicating that the mean condition has changed during the period of record. Qualitatively, all seven flow metrics in the CRB have remained stable since the 1930s, except for 7-day low flows in winter, which have increased by $12 \%$ since $1975(p<0.01)$ (Fig. 5).

Unlike the Chippewa, flow metrics in the Minnesota, Red, and Illinois river basins have systematically increased in recent decades, with nearly a 2-fold increase or greater in almost all flow metrics since 1975 (Fig. 5). Seven-day low flows in summer and winter (i.e., the lowest annual flows) have increased most in these basins, where mean conditions have increased by $67-275 \%(p<0.001)$ since 1975 (Fig. 5b). In much smaller basins, Xu et al. (2013) also reported the greatest streamflow changes to baseflows. High flow and extreme flow days have also increased significantly in the MRB $(p<0.001)$, IRB $(p<0.05)$, and RRB $(p<0.001)$. Spring peak daily flows have changed least in all basins, indicating $14 \%(p>0.05), 37 \%(p<0.05)$, and $60 \%(p<0.05)$ increases in mean between 1934-1974 and 1975-2013 for the IRB, MRB, and RRB, respectively (Fig. 5b). The Minnesota River basin has seen the greatest percent increase in mean annual flow, peak daily flow summer and fall, 7-day low flow in winter, high flow days and extreme flow days (Fig. 5b). Peak daily flow summer and 7 - 


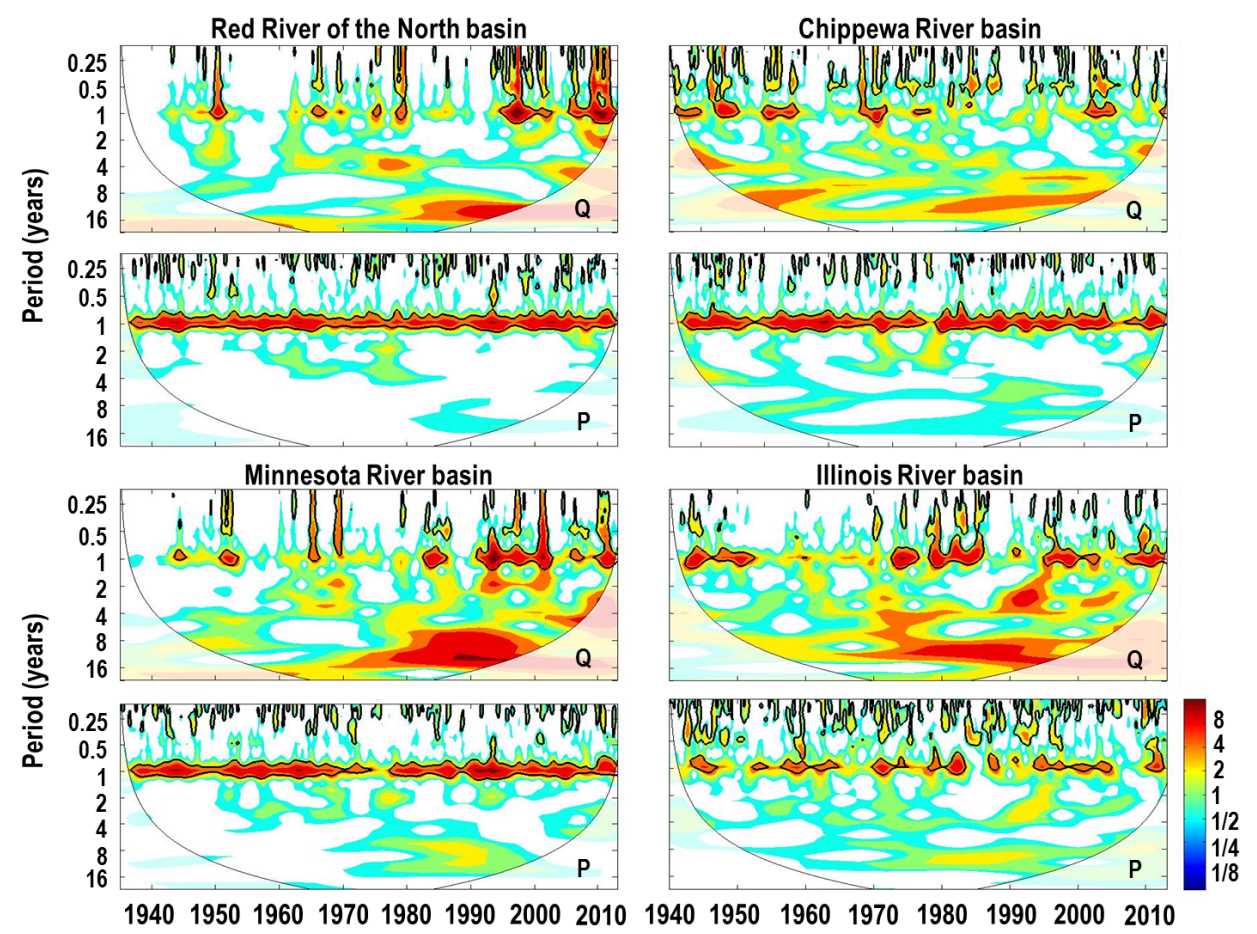

Figure 4. Continuous wavelet transform $(C W T)$ energies for monthly volumetric streamflow $(Q)$ and precipitation $(P)$ time series.

day low flow in summer have increased most in the Red River of the North basin (Fig. 5b).

All seven flow statistics in the Red River of the North basin increase dramatically after the mid-1990s (Fig. 5a). Low flows have increased 3.5-4 fold $(p<0.001)$ and high and extreme flows have increased $2.5-3$ fold $(p<0.001)$ in the RRB since 1995 (Fig. 5b). Flows in the Minnesota River basin have increased similarly, with a 3-4 fold increase in low flows $(p<0.001)$ and a 3 fold increase in high and extreme flows $(p<0.001)$ since the timing of land cover transition. Changes in the Illinois River basin are less obvious, yet still significant, with a 2 fold increase in low flows $(p<0.001)$ and a 1.5 fold increase in high and extreme flows $(p<0.05)$ since LCT.

The MRB and RRB exhibit an increase not only in the magnitude, but also in the cyclicity and synchronicity of these metrics after about 1980 (Fig. 5a). Cyclicity could imply that climate is playing a role in the observed increase in flows. However, the extent to which agricultural land and water management practices may be amplifying this climate effect cannot be ascertained from this figure alone. The Illinois River basin exhibits the most change in summer and winter 7-day low flows, which increase after 1970, and this trend is even more pronounced when only examining gauges within predominantly agricultural sub-basins that are unaffected by large dams (Fig. 5c). However, the changes in the RRB and MRB are much more obvious and statistically significant than those in the IRB.
Statistical results for annual changes in streamflow and precipitation for all breakpoints can be found in Table S1 in the Supplement. The following results are based on the 1974/1975 breakpoint. Overall, average annual streamflow, precipitation, and evapotranspiration depths have increased significantly in the MRB and RRB, while only streamflow has increased significantly in the IRB; no significant changes are reported in the CRB. Average annual runoff depth at the outlet gauge of the MRB has increased by $5.9 \mathrm{~cm}$ $(p<0.001)$. Average annual precipitation and evapotranspiration depths in the MRB have also increased by $4.6 \mathrm{~cm}$ $(p=0.033)$ and $3.3 \mathrm{~cm}(p=0.021)$, respectively. The average annual runoff ratio has increased from 0.11 to 0.18 , equivalent to a $65 \%$ increase and consistent with the results of Vandegrift and Stefan (2010). In the RRB, the average annual runoff ratio has increased by $65 \%$, from 0.07 to 0.11 at the outlet gauge, which is slightly greater than the $55 \%$ increase reported by Vandegrift and Stefan (2010). On average, annual runoff, precipitation, and evapotranspiration depths have increased by $2.9 \mathrm{~cm}(p<0.01), 4.1 \mathrm{~cm}(p=0.019)$, and $2.4 \mathrm{~cm}(p=0.043)$, respectively. Average annual runoff in the IRB has increased by $5.4 \mathrm{~cm}(p=0.011)$. Precipitation and evapotranspiration are likely increasing in the IRB; however, given the statistical power, the apparent $4.2 \mathrm{~cm}$ $(p=0.086)$ and $1.9 \mathrm{~cm}(p=0.072)$ increases were not significant. The average annual runoff ratio in the IRB has increased from 0.30 to 0.34 , a $14 \%$ increase. The CRB average runoff ratio has decreased slightly ( $2 \%$, from 0.37 to 0.36 . 

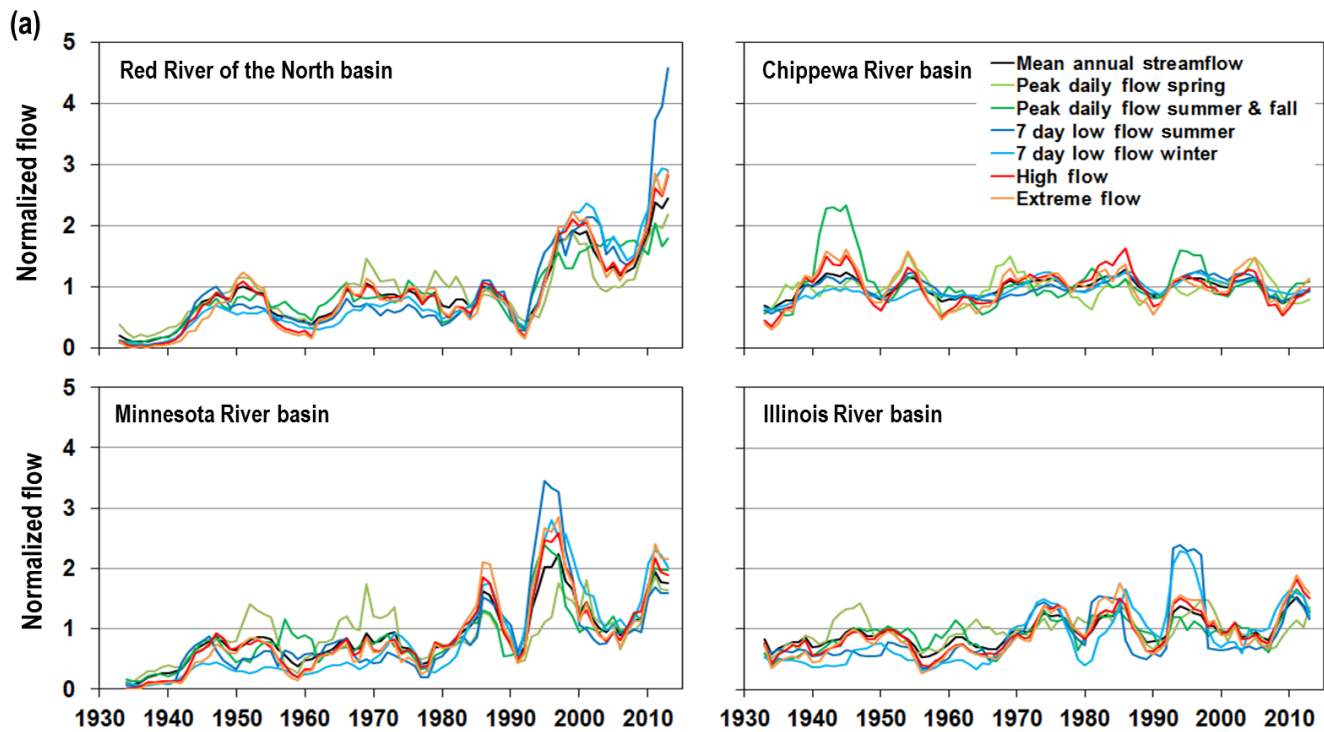

(b)

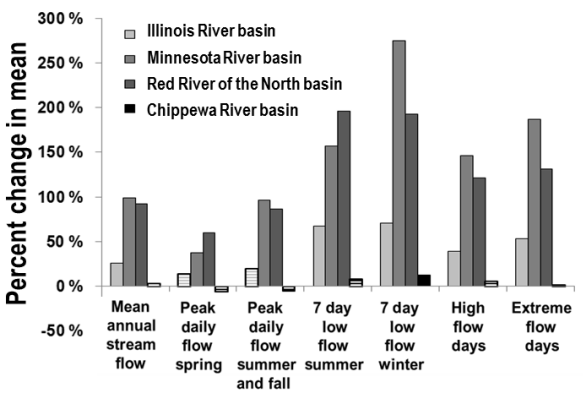

(c) Illinois River basin - agricultural tributaries

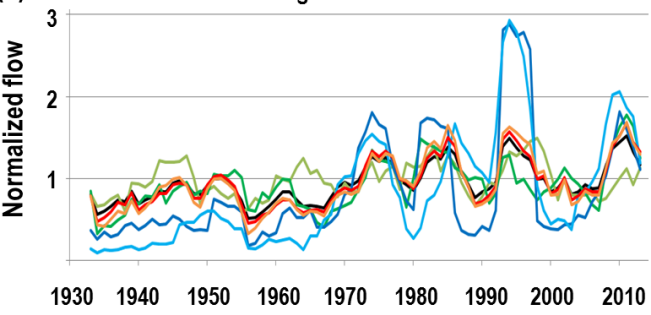

Figure 5. (a) Seven normalized streamflow metrics presented as 5-year running averages based on annual and daily gauge analysis for the Red River of the North basin, 22 gauges; Chippewa River basin, 9 gauges; Minnesota River basin, 12 gauges; and Illinois River basin, 20 gauges. (b) Percent change in flow metric mean between 1934-1974 and 1975-2013. Solid bars indicate significant increases in means $(\alpha=0.05)$. (c) Streamflow metrics for seven Illinois River basin tributary gauges that are predominately agricultural and not influenced by major dams. Annual flow metrics normalized by the 1950-2010 mean. Refer to Table 1 for gauge station details.

On average, annual runoff depth in the CRB has not changed $(0.00 \mathrm{~cm} ; p=0.499)$. Average precipitation and evapotranspiration depths may have increased slightly, perhaps by as much as $2.0 \mathrm{~cm}(p=0.243)$ and $0.9 \mathrm{~cm}(p=0.209)$, respectively, but these changes were not statistically significant.

The MRB and RRB exhibit the greatest change in the annual runoff ratio, followed by the IRB, with negligible change in the CRB. These findings are consistent with the fact that the MRB and RRB have relatively low runoff ratios comparted to the CRB and IRB, and are the only two basins where annual precipitation and evapotranspiration increases were statistically significant. On average, the fraction of annual precipitation that goes as ET has decreased $1.0-2.4 \%$ in all four study basins, which is smaller in magnitude but consistent in direction of change with Schottler et al. (2014) who found the ratio of PET / $P$ decreased $5.6 \%$ between 1940 1974 and 1975-2009 in a subbasin of the MRB. Schottler et al. (2014) considered the effects of both climate and cropping practices in calculations of PET while the Livneh et al. (2013) calculated $\mathrm{ET}_{\mathrm{a}}$ only considering climate. Modern decreases in PET / $P$ ratios in Midwestern agricultural watersheds are also reported by Xu et al. (2013).

\subsubsection{Monthly-scale changes in precipitation and streamflow}

Cumulative monthly precipitation, plotted in Fig. 6, indicates no systematic change in cumulative precipitation with time (i.e., constant slope) for any basin. However, cumulative monthly streamflow (1935-2013) plotted in Fig. 6 indicates a sudden change in slope around 1973 in the IRB, 1980 in the MRB, and 1995 in the RRB, without a distinct change in slope in the CRB. The visually identified change points are consistent with those identified from the CWT (Fig. 4).

Statistical tests of monthly streamflow and precipitation resulted in the same interpretations for $95 \%$ of the tests regardless of the breakpoint (Table S1 in the Supplement); therefore Fig. 7 summarizes the results of these statistical tests for flow and precipitation in all basins using the 


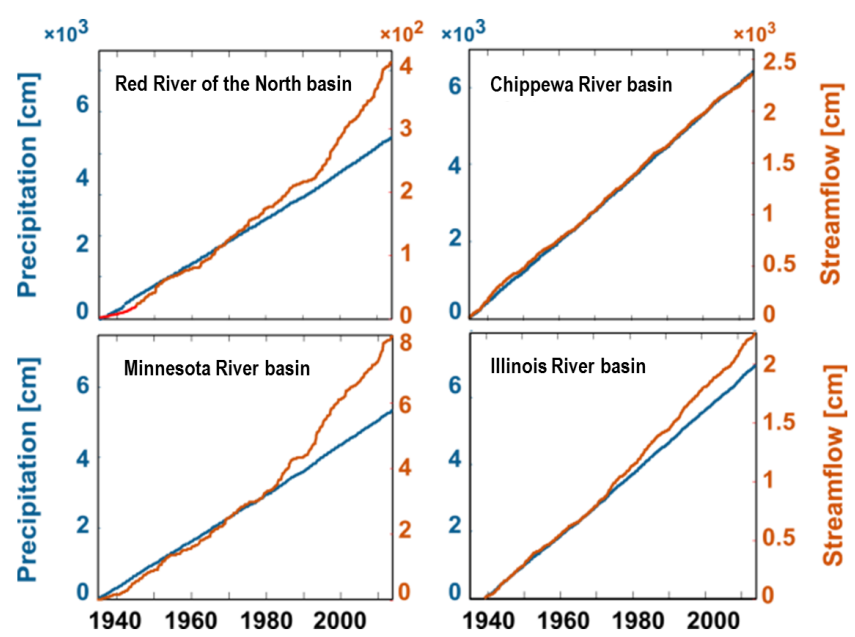

Figure 6. Cumulative monthly precipitation (blue) and streamflow (red) depths $(\mathrm{cm})$ for each river basin. Breakpoints, where the streamflow-precipitation relationship starts to change, are hard to detect from the time series alone, but can be clearly seen from the cumulative plots of the monthly data (i.e., when similar increments of monthly precipitation are translated into larger amounts of monthly streamflow).

1974/1975 breakpoint. Figure 7a illustrates the kernel density estimation, or non-parametric estimation of the probability density function, during the pre-period and post-period for June and September flows in each basin. Figure 7b reports 192 results (48 $p$ values reported per basin) from the monthly streamflow and precipitation $t$ tests and KS tests. Each color wheel displays 24 results, 2 results per month for each basin, and shows significant $p$ values for $t$ tests and KS tests based on color. Color is inversely related to $p$ value such that smaller $p$ values and thus more significant results are shown in increasingly darker colors, with $p$ values greater than 0.05 colored white. As such the streamflow color wheel in Fig. $7 \mathrm{~b}$ for the Chippewa River basin is completely white, indicating there were no statistically significant changes in the mean or distribution of monthly streamflow volumes for any months, consistent with the assessment of the seven annual streamflow metrics and cumulative streamflow (Figs. 5 and 6). We report a significant increase in mean October precipitation in the CRB. Monthly results for flow and precipitation changes in the CRB are consistent with the annual changes reported earlier.

In stark contrast to the CRB, the streamflow color wheels for the MRB and RRB show significant changes in mean and distribution of monthly streamflow for nearly all months (22 out of 24 for MRB and 21 out of 24 for RRB) (Fig. 7b). In the RRB, mean precipitation in October has increased, and the precipitation distributions have shifted to the right for September and October (Fig. 7b). In the MRB, there has been a significant increase in mean March precipitation (Fig. 7b). The IRB exhibits fewer overall changes in streamflow than the RRB and MRB, with significant changes in monthly streamflow volumes for September, October, November, December and March, and significant changes in August and November precipitation (Fig. 7b).

We acknowledge that due to high variability and small sample sizes, we may not have sufficient power to detect small but real changes in precipitation and streamflow using these statistical tests, and thus may be prone to Type II error (Belmont et al., 2016). However, these results are consistent with the qualitative assessment of CWT, results of the seven annual flow statistics, and cumulative precipitation and streamflow trends, which indicate only slight changes in total precipitation across all basins, large increases in total flow in the MRB and RRB, moderate flow increases in the IRB, and no streamflow changes in the CRB (Figs. 4, 5, and 6).

To understand whether the cause and effect interconnection of streamflow $(Q)$ and precipitation $(P)$ has changed, we plotted the joint probability distribution functions (joint PDFs) of monthly $P$ and $Q, f(P, Q)$, for each basin (Fig. 8). A joint PDF of pairs of monthly $P$ and $Q$ is the chance of their occurrence simultaneously. In Fig. 8 we illustrate three empirical quantiles of the joint PDFs through contour levels $\alpha \in\{0.1,0.6,0.9\}$, where each contour level represents the boundary of a discrete 2-D space in which the probability of each $(P, Q)$ pair falling inside that 2-D space is alpha. A shift in the contour levels in the vertical, rather than diagonal, direction suggests that changes in precipitation magnitude alone cannot explain changes in streamflow, and some other component of the system must be amplifying the transformation of precipitation to runoff at the monthly timescale.

There is a shift toward a larger monthly streamflow volume for the same volume of precipitation at each 10 and $60 \%$ quantile in the MRB and 60 and $90 \%$ quantile in the RRB (Fig. 8). However, it appears the $90 \%$ exceedance contour for the MRB and $10 \%$ exceedance contour for the RRB have shifted up and to the right, indicating that an increase in precipitation in the driest months in the MRB and wettest months in the RRB could also be driving some of the change in flow (Fig. 8). Certainly the largest observable change in the MRB and RRB during this time is a shift from small grains to soybeans and an increase in the density and efficiency of drain tile networks. While the analyses shown above documented significant changes in the streamflow of the IRB (Figs. 4, 5, 6, and 7b), this change is not as obvious in these joint PDF contours, which indicate only a slight vertical shift in all quantiles (Fig. 8). Consistent with other analyses, the CRB does not demonstrate any shift in the $P-Q$ relation, suggesting that the streamflow has been largely unaffected by the observed slight increase in annual precipitation in the basin (Fig. 8).

\subsubsection{Daily-scale changes in streamflow}

At the daily scale, we found an increase in the magnitude of streamflow change (hydrograph slopes) for both the daily ris- 
(a)
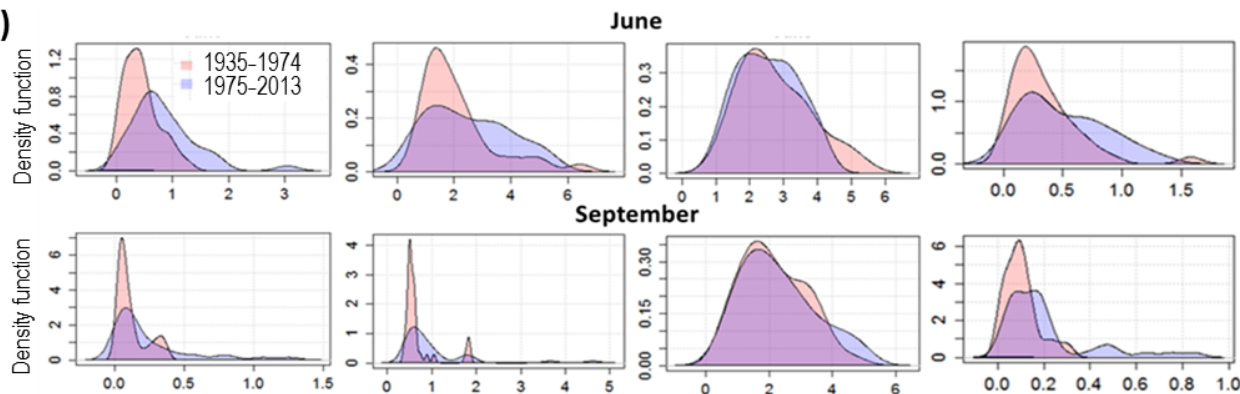

Monthly streamflow volume $\left(\mathrm{km}^{3}\right)$ Monthly streamflow volume $\left(\mathrm{km}^{3}\right)$ Monthly streamflow volume $\left(\mathrm{km}^{3}\right)$

Monthly streamflow volume $\left(\mathrm{km}^{3}\right)$

(b)

\section{Minnesota River basin}
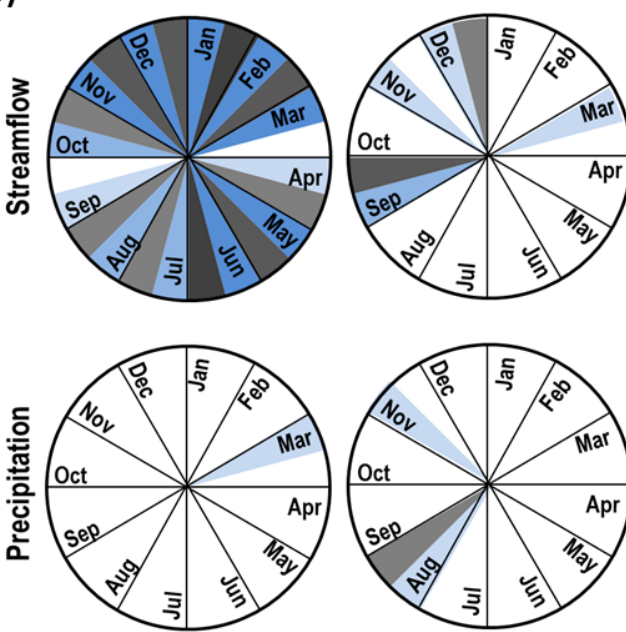

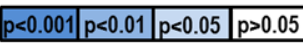

Significance $t$ test (mean)
Chippewa River basin

\section{Red River of the North basin}
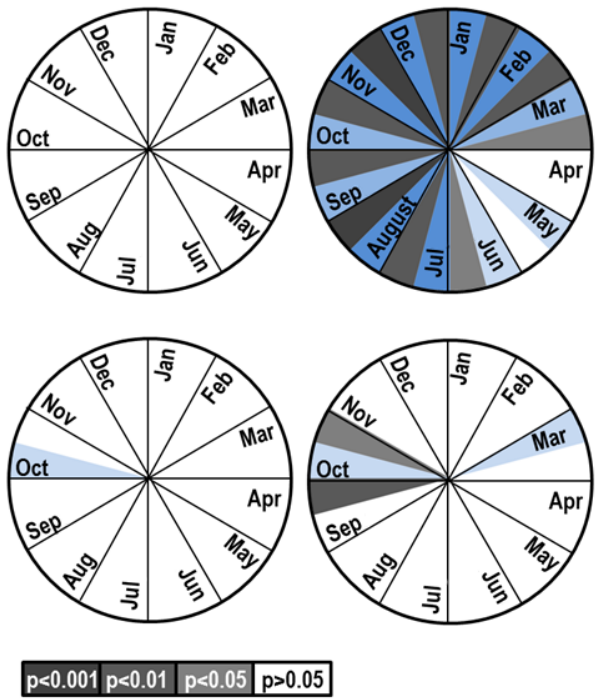

Significance K-S test (distribution)

Figure 7. (a) Kernel density plots of monthly streamflow volumes for June and September for each basin. (b) Corresponding significance results for $t$ tests and Kolmogorov-Smirnov (KS) tests $(\alpha=0.05)$ of monthly streamflow and precipitation volumes in each basin, where a significant result indicates a positive shift (increase) in the mean or distribution between 1935-1974 and 1975-2013; color wheels collectively display 192 individual $p$ values.

ing limbs $(\mathrm{d} Q / \mathrm{d} t>0)$ and falling limbs $(\mathrm{d} Q / \mathrm{d} t<0)$ of the hydrographs for RRB, MRB, and IRB outlet gauges, suggesting an increase in flashiness, or daily rate of change, of the hydrologic response (Fig. 9). Figure 9 shows a slight decrease in the post-period curve for the CRB, indicating that the rising limb and falling limb flows may actually be less flashy in recent times than in the past. May-June is approximately the start of the growing season for soybean and corn and it is the time that tiles are most active, as this time of year usually corresponds to high monthly rainfall, high antecedent moisture conditions from spring snowmelt, and lower ET rates than the peak growing season due to lower crop water demands, and air temperatures that precede the annual peak.

\subsection{Hydrologic budgets suggest declining watershed storage in drained agricultural basins}

While time series and statistical analyses reveal useful insights regarding the timing, magnitude, and significance of precipitation and streamflow changes, as well as provide a qualitative indication of whether or not changes in precipitation and streamflow may be correlated and proportional, they cannot fully deconvolve or attribute the influence of artificial drainage and climate on streamflows (Harrigan et al., 2014). Therefore, we calculate water budgets for each basin as a tool to understand whether the observed changes in precipitation are large enough to account for the changes in streamflow, and whether there is more or less watershed storage in recent times than in the past (Healy et al., 2007).

Table 4 reports the calculated average annual water budget terms - precipitation, streamflow, evapotranspiration, and change in storage - during the periods before and after the 
Table 4. Observed average annual precipitation $(P)$, flow $(Q)$, evapotranspiration $\left(\right.$ ET), and storage $\left(\frac{\mathrm{d} S}{\mathrm{~d} t}\right) \mathrm{depths}\left(\mathrm{cm} \mathrm{yr}^{-1}\right)$ for each basin during the pre-period (a) and post-period (b) split by 1974/1975 (1) and land cover transition (LCT) (2) breakpoints.

\begin{tabular}{|c|c|c|c|c|c|c|}
\hline & & Years & $\begin{array}{r}P_{\text {mean }} \\
\left(\mathrm{cm} \mathrm{yr}^{-1}\right)\end{array}$ & $\begin{array}{r}Q_{\text {mean }} \\
\left(\mathrm{cm} \mathrm{yr}^{-1}\right)\end{array}$ & $\begin{array}{r}\mathrm{ET}_{\text {mean }} \\
\left(\mathrm{cm} \mathrm{yr}^{-1}\right)\end{array}$ & $\begin{array}{r}\frac{\mathrm{d} S}{\mathrm{~d} t_{\text {mean }}} \\
\left(\mathrm{cm} \mathrm{yr}^{-1}\right)\end{array}$ \\
\hline \multirow[t]{8}{*}{ Minnesota River basin } & $1 \mathrm{a}$ & $1935-1974$ & 65.1 & 7.2 & 60.9 & -3.0 \\
\hline & $1 b$ & $1975-2011$ & 70.0 & 13.4 & 64.2 & -7.5 \\
\hline & $2 \mathrm{a}$ & $1935-1978$ & 64.8 & 7.0 & 60.6 & -2.8 \\
\hline & $2 b$ & 1979-2011 & 71.0 & 14.4 & 65.0 & -8.4 \\
\hline & $1 a^{*}$ & $1935-1974$ & 65.1 & 7.2 & 55.6 & 2.3 \\
\hline & $1 b^{*}$ & $1975-2011$ & 70.0 & 13.4 & 58.7 & -2.0 \\
\hline & $2 a^{*}$ & $1935-1978$ & 64.8 & 7.0 & 55.4 & 2.4 \\
\hline & $2 b^{*}$ & 1979-2011 & 71.0 & 14.4 & 59.3 & -2.7 \\
\hline \multirow[t]{8}{*}{ Red River of the North basin } & 1a & 1935-1974 & 53.4 & 3.7 & 45.1 & 4.7 \\
\hline & $1 b$ & 1975-2011 & 57.7 & 6.7 & 47.4 & 3.5 \\
\hline & $2 \mathrm{a}$ & $1935-2003$ & 54.5 & 4.6 & 45.6 & 4.4 \\
\hline & $2 b$ & 2004-2011 & 63.3 & 10.1 & 51.6 & 1.5 \\
\hline & $1 a^{*}$ & $1935-1974$ & 53.4 & 3.7 & 41.1 & 8.6 \\
\hline & $1 b^{*}$ & 1975-2011 & 57.7 & 6.7 & 43.3 & 7.6 \\
\hline & $2 a^{*}$ & 1935-2003 & 54.5 & 4.6 & 41.6 & 8.4 \\
\hline & $2 b^{*}$ & 2004-2011 & 63.3 & 10.1 & 47.4 & 5.8 \\
\hline \multirow[t]{8}{*}{ Illinois River basin } & $1 \mathrm{a}$ & 1939-1974 & 90.5 & 27.3 & 73.2 & -10.0 \\
\hline & $1 b$ & 1975-2011 & 95.2 & 33.0 & 75.1 & -13.0 \\
\hline & $2 \mathrm{a}$ & 1939-1961 & 89.5 & 25.9 & 72.8 & -9.3 \\
\hline & $2 b$ & 1962-2011 & 94.4 & 32.2 & 74.8 & -12.5 \\
\hline & $1 a^{*}$ & 1939-1974 & 90.5 & 27.3 & 66.9 & -3.7 \\
\hline & $1 b^{*}$ & $1975-2011$ & 95.2 & 33.0 & 68.7 & -6.6 \\
\hline & $2 a^{*}$ & 1939-1961 & 89.5 & 25.9 & 66.5 & -3.0 \\
\hline & $2 b^{*}$ & $1962-2011$ & 94.4 & 32.2 & 68.4 & -6.1 \\
\hline \multirow[t]{8}{*}{ Chippewa River basin } & $1 \mathrm{a}$ & 1935-1974 & 80.0 & 29.7 & 61.8 & -11.5 \\
\hline & $1 b$ & 1975-2011 & 82.1 & 29.8 & 62.7 & -10.5 \\
\hline & $2 \mathrm{a}$ & 1935-2009 & 80.8 & 29.6 & 62.1 & -11.0 \\
\hline & $2 b$ & 2010-2011 & 88.4 & 33.3 & 68.5 & -13.4 \\
\hline & $1 a^{*}$ & 1935-1974 & 80.0 & 29.7 & 56.5 & -6.2 \\
\hline & $1 b^{*}$ & 1975-2011 & 82.1 & 29.8 & 57.4 & -5.2 \\
\hline & $2 a^{*}$ & 1935-2009 & 80.8 & 29.6 & 56.8 & -5.7 \\
\hline & $2 b^{*}$ & 2010-2011 & 88.4 & 33.3 & 62.3 & -7.3 \\
\hline
\end{tabular}

* $17 \%$ reduction in ET during summer months (JJA).

1974/1975 and LCT breakpoint using raw and conservative (reduced by $17 \%$ in JJA) estimates of $\mathrm{ET}_{\mathrm{a}}$. We find that, regardless of the breakpoint or raw vs. conservative estimates of $\mathrm{ET}_{\mathrm{a}}$, there is a net reduction in water stored in soil, groundwater, and/or lakes, wetlands, or reservoirs between the preperiod and post-period in the MRB, RRB, and IRB (Table 4). The most parsimonious explanation for this reduction in water storage is the systematic removal of wetlands and lowering of the water table, accomplished through tile drainage installation and expansion.

The CRB, which is not intensively drained (Fig. 2) and has experienced little change in crop type (Fig. 3), has been subject to an increase in precipitation, but does not exhibit an increase in runoff (Table 4), consistent with Figs. 8 and 9b. The overall trends in the CRB water budget indicate that water storage may have actually increased slightly between the pre-period and post-period, which could be accomplished through increased soil moisture, groundwater recharge, or reservoir storage in recent times.

Using conservative estimates of summer $\mathrm{ET}_{\mathrm{a}}$ the change in storage term has decreased by about 200,100 , and $30 \%$, in the MRB, IRB, and RRB from the pre-LCT-period to postLCT-period. In the CRB, change in storage has increased by roughly $30 \%$ from $1935-1974$ to $1975-2011$. These results are consistent with our hypothesis that increases in artificial drainage in the MRB, RRB, and IRB necessarily change how precipitation is transformed into streamflow and that increases in precipitation alone cannot explain 

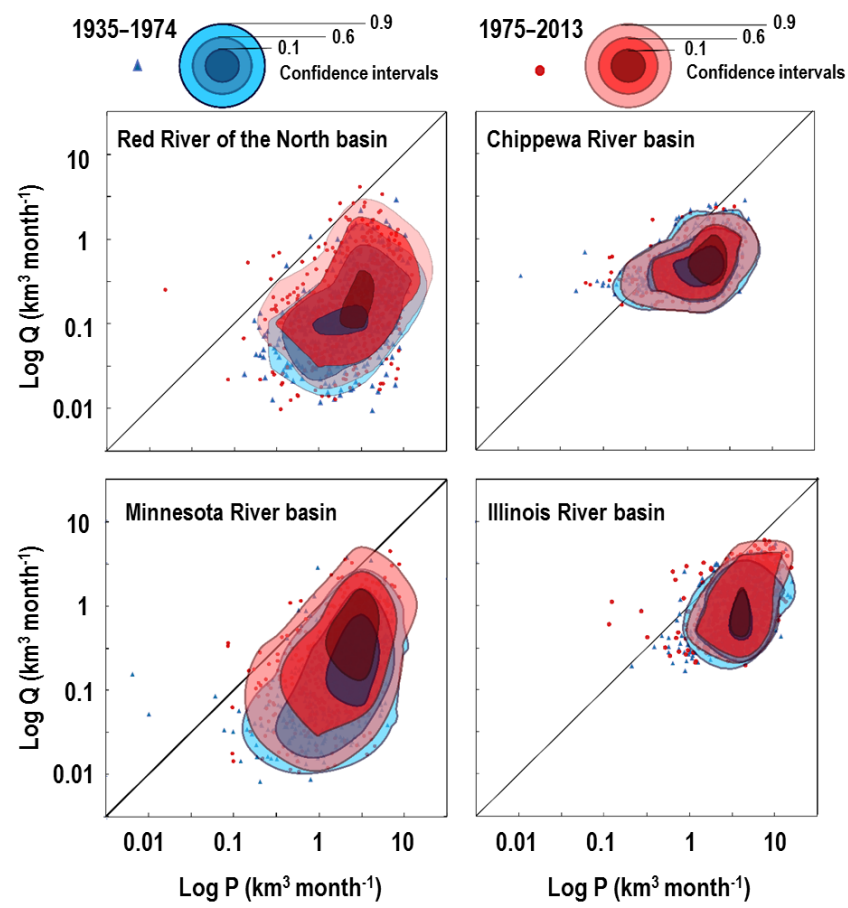

Figure 8. Log-log empirical quantiles of joint PDF plots of monthly streamflow $(Q)$ versus monthly precipitation $(P)$ volumes for each river basin during the pre-period (blue: 1935-1974) and post-period (red: 1975-2013); bulls eye shading represents the 0.1 (dark), 0.6 (medium), and 0.9 (light) confidence intervals.

changes in streamflow in these basins. Without pervasive artificial drainage in the CRB, while precipitation has increased slightly, flows have not changed, likely due to increases in soil moisture, groundwater, and/or lake, wetland and reservoir storage. Seasonal changes in storage shown in Fig. 10 suggest that soil moisture, groundwater, and/or lake, wetland, and reservoir storage in the spring and summer is negative, suggesting not enough $P$ given $\mathrm{ET}_{\mathrm{a}}$ to produce observed flows, and positive in the fall suggesting more $P$ and $\mathrm{ET}_{\mathrm{a}}$ than necessary to produce observed flows and thus an increase in storage during the fall.

The Red River of the North and Minnesota River basins have some of the poorest drained soils of the Upper Midwest and historically grew more hay and small grains than the other basins (Fig. 3). The introduction of artificial drainage combined with the replacement of hay and small grains with soybeans and the lack of major dams and municipal and industrial water use, has resulted in pronounced streamflow amplification in response to land use and climate changes in the RRB and MRB relative to the IRB and CRB (Fig. 4). Additionally these two basins have seen greater changes in annual and even monthly precipitation (Figs. 7 and 8). However, the extensively drained Minnesota River Basin has seen the largest increases in flow and largest decrease in watershed storage for relatively similar climatic change to the IRB and RRB, and this is likely because of the high degree of watershed hydrologic alteration and connectivity from drainage and lack of other anthropogenic water uses.

\section{Interpretations, implications, and conclusions}

In this paper we address three research questions: (1) how have LULC, climate, and streamflows changed during the twentieth and twenty-first centuries; (2) what are the timing, timescales and times of year where changes are most prominent; and (3) can changes in climate alone explain changes in streamflow? The combined results of this study lead us to several main conclusions. First, widespread drainage expansion and intensification, especially of tile drainage, coupled with conversion of hay and small grains to corn and soybeans is evident and continues to occur in agricultural river basins. Annual precipitation and evapotranspiration totals have increased since 1975, though we found these changes to only be statistically significant in the MRB and RRB. Monthly precipitation increases are generally not significant except in fall months for all basins. Additionally, across multiple scales (daily, monthly, annual) and for a range of flows (low, mean, extreme), streamflows have increased at all times of the year in intensively managed agricultural watersheds (IRB, MRB, and RRB) and have remained stationary in the more forested CRB. The magnitude and timing of precipitation increases in each watershed suggest that precipitation contributes to recently observed increases in streamflow, consistent with other findings in the Midwestern USA (Frans et al., 2013; $\mathrm{Xu}$ et al., 2013). Despite this apparent correlation, the magnitude of precipitation increases alone cannot explain the observed increases in flow for agricultural basins according to the water balances. Therefore, it appears that the pervasive and extensive artificial drainage in agricultural basins has contributed to increased streamflow, not only at $10^{2}-10^{3} \mathrm{~km}$ watershed scales (e.g., Foufoula-Georgiou et al., 2015; Harrigan et al., 2014; Schilling and Libra, 2003; Schottler et al., 2014; Xu et al., 2013; Zhang and Schilling, 2006), but also at the scale of the very large basins studied here.

Harrigan et al. (2014) recognize that often multiple drivers explain hydrologic change. These drivers are not mutually exclusive and may even act synergistically to explain observed streamflow trends. In the Midwestern USA possible explanations that could explain substantial streamflow increases include (1) changes in storm duration and intensity or the amount of precipitation falling as rain versus snow, changing the characteristics of runoff generation while having little change in monthly or annual precipitation magnitudes; (2) increases in precipitation translating into increases in soil moisture, which contributes to amplified flows; and (3) artificial drainage more efficiently routing sub-surface flow to streams, an effect which could be amplified by increased precipitation. 

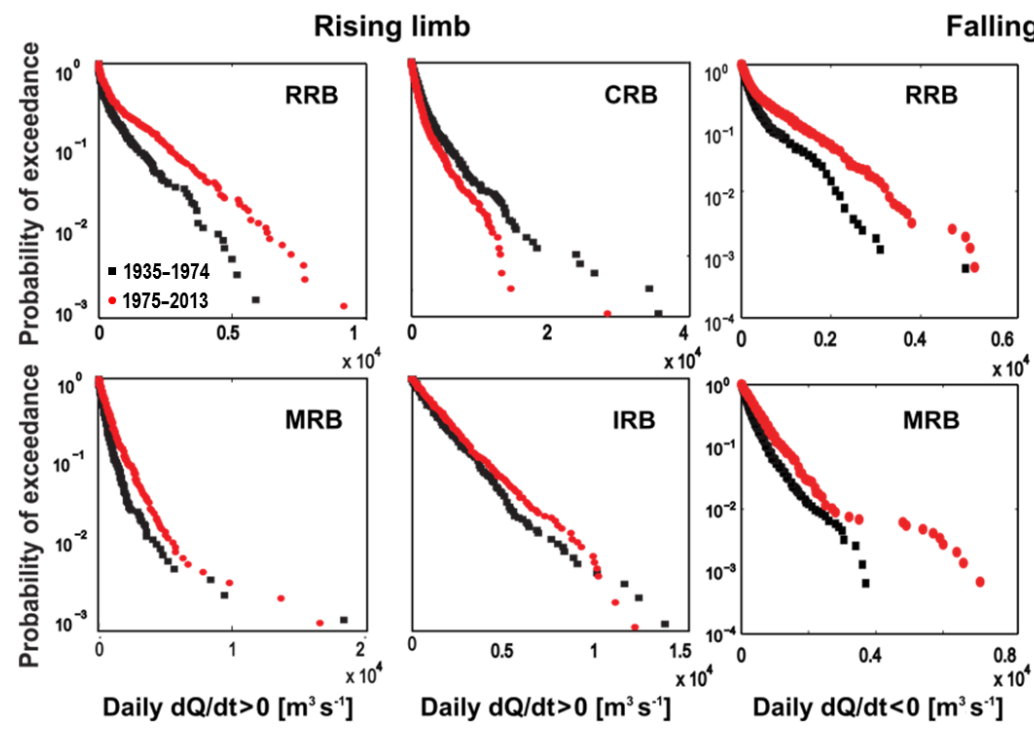

Falling limb
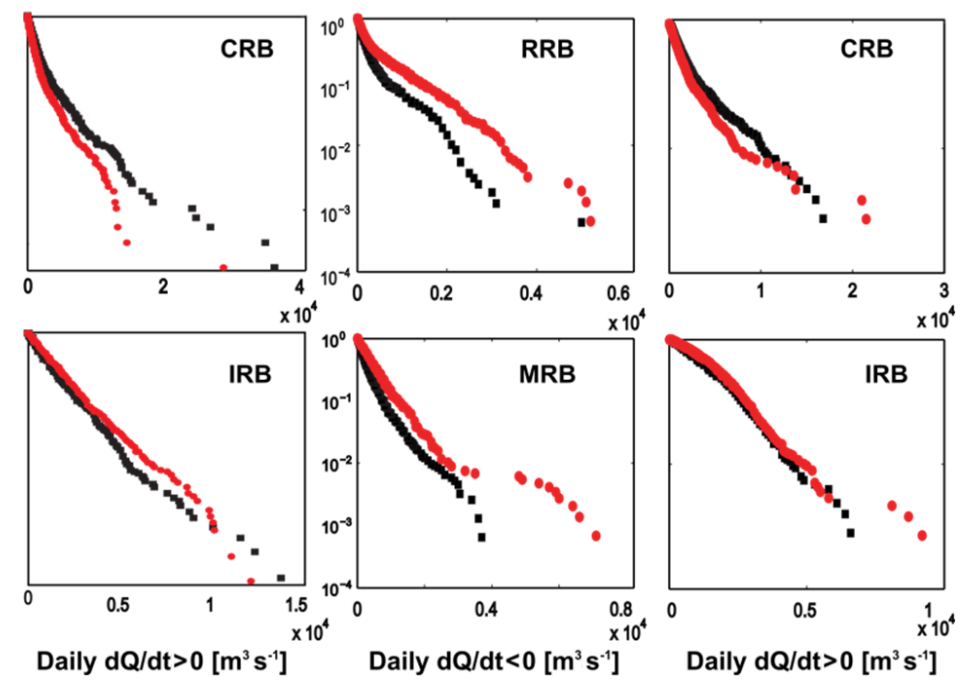

Figure 9. Daily streamflow change exceedance probabilities, where daily $\mathrm{d} Q / \mathrm{d} t>0$ characterizes rising limb flows and daily $\mathrm{d} Q / \mathrm{d} t<0$ characterizes falling limb flows. Study basin acronyms are defined as follows: Red River of the North basin (RRB), Minnesota River basin (MRB), Chippewa River basin (CRB), and Illinois River basin (IRB).

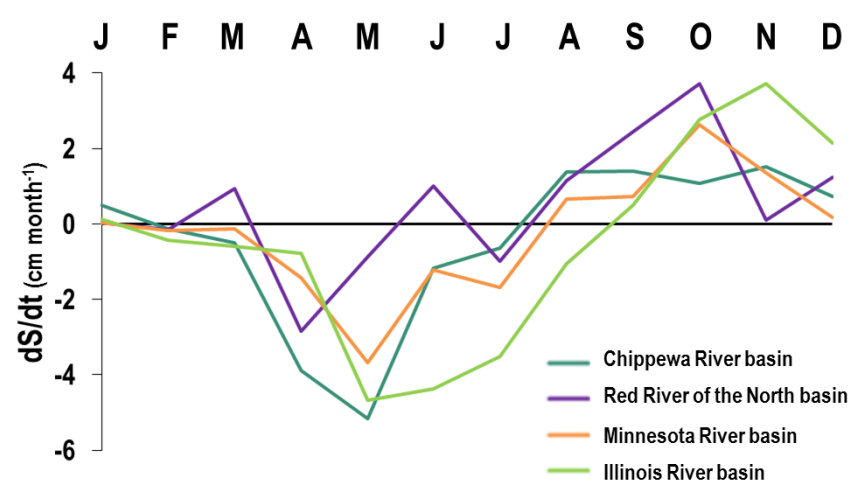

Figure 10. Average monthly (January-December) change in basin soil moisture, groundwater, and/or reservoir storage ( $\mathrm{d} S / \mathrm{d} t)$, calculated after land cover transition (LCT) years (see Table 3 for the Illinois River basin, Minnesota River basin, and Red River of the North basin LCT years), and after 1975 for the Chippewa River basin assuming a $17 \%$ reduction in $\mathrm{ET}_{\mathrm{a}}$ for summer months.

First, it is theoretically possible to observe changes in streamflow while having no change in monthly or annual precipitation magnitudes. High intensity, short duration events yield higher runoff ratios in poorly drained soils. Additionally warmer winter temperatures, earlier snowmelt, and more days when winter precipitation falls as rain instead of snow should affect and even increase winter baseflows, decrease the timing of ice break-up, and affect the magnitude of snowmelt floods. Several studies have documented such hydroclimate changes in the Midwestern USA (Feng and Hu, 2007; Groisman et al., 2001; Higgins and Kousky, 2012) and the role of these hydroclimate changes could be explored by future investigations.

Second, increased soil moisture is known to cause a nonlinear increase in runoff generation for similar precipitation events. Meyles et al. (2003) and Penna et al. (2011) report a threshold response in runoff generation when antecedent soil moisture exceeds $65 \%$ of the soil porosity. It is possible that soil moisture has increased throughout the Midwestern US. However, no theory exists to predict how big this effect could be on landscape scales $\left(>10^{4} \mathrm{~km}^{2}\right)$. Furthermore, there are very limited data to determine whether or not soil moisture has in fact increased beyond such a threshold despite the immense amount of additional tile drainage that has been installed in the past few decades. Investigating this effect would be a good future step in this line of research.

Third, several previous studies have demonstrated that artificial drainage increases streamflow in moderate sized $\left(10^{2}-10^{3} \mathrm{~km}^{2}\right)$ watersheds (Schottler et al., 2014; FoufoulaGeorgiou et al., 2015). Though we cannot fully rule out the first and second mechanisms discussed above, artificial drainage for corn-soy agriculture affects substantial swaths of land in all study watersheds except the Chippewa, and has almost doubled in area in the MRB and IRB since 1940 according to the US Census of Agriculture reports. It is known qualitatively that drainage has increased in density and efficiency during this same time. Using multiple lines of evidence from the analyses of very large basins and sub-basins it appears most likely that widespread agricultural drainage activities have amplified the streamflow response to relatively small changes in total precipitation. Frans et al. (2013) found that artificial drainage amplified annual runoff in the Upper Mississippi River basin in some cases by as much as $40 \%$ 
locally. Improved information regarding the size, spacing, depth, and extent of artificial drainage would greatly enhance our ability to model agricultural systems and predict downstream impacts.

Surface and subsurface drainage remains largely unregulated throughout the Midwestern USA and Canada (Cortus et al., 2011). Drainage census data are prone to reporting inconsistencies and errors, overall underestimation of drainage from excluding farms less than 500 acres, and do not provide the information necessary for modeling basin hydrology in large agricultural watersheds (such as drain size, depth, spacing, and extent). However, these are the most comprehensive inventory of drainage in the United States. This raises the question: why is such a widespread practice with such potentially profound and pervasive impacts on watershed hydrology and water quality so poorly documented and regulated? Until we have the information necessary to calibrate and validate watershed models, it will be difficult to more precisely deconvolve proportional impacts of climate and artificial drainage on flows at large spatial scales.

Decreased residence time of water in the soil has substantially increased nutrient export from agricultural landscapes (Randall and Mulla, 2001; Kreiling and Houser, 2016; Schilling et al., 2017). Though artificial drainage reduces field erosion by reducing surface runoff, it has been shown to essentially have shifted the sediment source from fields to channels (Belmont, 2011; Belmont and Foufoula-Georgiou, 2017). Basins experiencing increases in streamflow due to natural (climate) and anthropogenic (drainage) factors have increased stream power available to erode and transport more sediments and sediment bound nutrients and contaminants. Improved runoff management, specifically increased residence time and damped peak flows, is most needed in spring and early summer when tiles are actively draining soils and precipitation events are large. Thus, substantial gains in water quality might only be achieved if some amount of the lost water storage capacity is reintroduced (e.g., wetlands, detention basins) into these agricultural watersheds.

Data availability. Precipitation and streamflow data are publicly available and were accessed from the PRISM Climate Group, http: //prism.oregonstate.edu/, and the United States Geological Survey, https://waterdata.usgs.gov/nwis, respectively. Livneh et al. (2013) evapotranspiration data provided by the NOAA/OAR/ESRL PSD, Boulder, Colorado, USA, from their website at http://www.esrl. noaa.gov/psd/. AmeriFlux evapotranspiration data are available at http://ameriflux.lbl.gov/. The Albert R. Mann Library at Cornell University maintains historical archives of United States Department of Agriculture Census of Agriculture reports from 1840 to 2002, available at http://agcensus.mannlib.cornell.edu/AgCensus/ homepage.do. The 2012 Census of Agriculture and National Cropland Data Layers are available from the United States Department of Agricultural, National Agricultural Statistics Service, https: //www.agcensus.usda.gov/. For questions regarding data availability, please contact the corresponding author.

\section{The Supplement related to this article is available online at https://doi.org/10.5194/hess-21-5065-2017- supplement.}

Competing interests. The authors declare that they have no conflict of interest.

Acknowledgements. This material is based upon work supported by the National Science Foundation (grant no. EAR-1209402) under the Water Sustainability and Climate Program (WSC): REACH (REsilience under Accelerated CHange), and by the National Science Foundation Graduate Research Fellowship Program under grant no. 1147384. This research was supported by the Utah Agricultural Experiment Station, Utah State University, and approved as journal paper number 8938 . The authors would like to thank Jon Czuba at Virginia Tech, and Karthik Kumarasamy, Eden Furtak-Cole, and Mitchell Donovan at Utah State University for their input. Thank you to Alexander Bryan at the Northeast Climate Science Center for generously providing evapotranspiration data from Bryan et al. (2015). Funding for AmeriFlux data resources was provided by the US Department of Energy's Office of Science.

Edited by: Nunzio Romano

Reviewed by: Ben Livneh, Boris Ochoa-Tocachi, and two anonymous referees

\section{References}

Addison, P. S.: The Illustrated Wavelet Transform Handbook: Introductory Theory and Applications in Science, Engineering, Medicine and Finance, edited by: Revill, J. and Laurenson, S., Institute of Physics, Philadelphia, 2002.

Anctil, F. and Coulibaly, P.: Wavelet Analysis of the Interannual Variability in Southern Québec Streamflow, J. Climate, 17, 163-173, https://doi.org/10.1175/15200442(2004)017<0163:WAOTIV>2.0.CO;2, 2004.

Arnold, T. L., Sullivan, D. J., Harris, M. A., Fitzpatrick, F. A., Scudder, B. C., Ruhl, P. M., Hanchar, D. W., and Stewart, J. S.: Environmental Setting of the Upper Illinois River Basin and Implications for Water Quality, US Geol. Surv. Water-Resources Investig. Rep. 98-4268, 1999.

Barnes, W. J.: Vegetation Dynamics on the Floodplain of the Lower Chippewa River in Wisconsin, J. Torrey Bot. Soc., 124, 189-197, 1997.

Beauchamp, K. H.: A History of Drainage and Drainage Methods, in: Farm Drainage in the United States: History, Status, and Prospects, Miscellaneous Publication No. 1455, edited by: Pavelis, G. A., 13-29, U.S. Department of Agriculture, Washington D.C., 1987.

Belmont, P.: Floodplain width adjustments in response to rapid base level fall and knickpoint migration, Geomorphology, 128, 92101, https://doi.org/10.1016/j.geomorph.2010.12.026, 2011.

Belmont, P. and Foufoula-Georgiou, E.: Solving water quality problems in agricultural landscapes: New approaches for these nonlinear, multiprocess, multiscale systems, Water Resour. Res., 53, 2585-2590, https://doi.org/10.1002/2017WR020839, 2017. 
Belmont, P., Gran, K. B., Schottler, S. P., Wilcock, P. R., Day, S. S., Jennings, C., Lauer, J. W., Viparelli, E., Willenbring, J. K., Engstrom, D. R., and Parker, G.: Large shift in source of fine sediment in the upper Mississippi River, Environ. Sci. Technol., 45, 8804-8810, https://doi.org/10.1021/es2019109, 2011.

Belmont, P., Willenbring, J. K., Schottler, S. P., Marquard, J., Kumarasamy, K., and Hemmis, J. M.: Toward generalizable sediment fingerprinting with tracers that are conservative and nonconservative over sediment routing timescales, J. Soils Sediments, 14, 1479-1492, https://doi.org/10.1007/s11368-0140913-5, 2014.

Belmont, P., Stevens, J. R., Czuba, J. A., Kumarasamy, K., and Kelly, S. A.: Comment on "Climate and agricultural land use change impacts on streamflow in the upper midwestern United States" by Satish C Gupta et al., Water Resour. Res., 52, 75237528, https://doi.org/10.1002/2015WR018476, 2016.

Blann, K. L., Anderson, J. L., Sands, G. R., and Vondracek, B.: Effects of Agricultural Drainage on Aquatic Ecosystems: A Review, Crit. Rev. Env. Sci. Tec., 39, 909-1001, https://doi.org/10.1080/10643380801977966, 2009.

Blue Earth County Minnesota: Online Drainage Portal, available at: https://blueearth.drainagedb.net/portal/\#portaldashboard.php, last access: 17 June 2016.

Bois de Sioux Watershed District: Calendar Year 2015 Annual Report, Wheaton, MN, available at: http://www.bdswd.com/ (last access: 19 September 2017), 2015.

Boucher, O., Myhre, G., and Myhre, A.: Direct human influence of irrigation on atmospheric water vapour and climate, Clim. Dynam., 22, 597-603, https://doi.org/10.1007/s00382-004-0402-4, 2004.

Boyd, C. and McNevin, A.: Aquaculture, Resource Use, and the Environment, Wiley-Blackwell, Hoboken, New Jersey, 2015.

Bryan, A. M., Steiner, A. L., and Posselt, D. J.: Regional modeling of surface-atmosphere interactions and their impact on Great Lakes hydroclimate, J. Geophys. Res.-Atmos., 120, 1044-1064, https://doi.org/10.1002/2014JD022316, 2015.

Bullock, A. and Acreman, M.: The role of wetlands in the hydrological cycle, Hydrol. Earth Syst. Sci., 7, 358-389, https://doi.org/10.5194/hess-7-358-2003, 2003.

Burns, B. E.: Artificial Drainage in Blue Earth County, Minnesota, University of Nebraska, 1954.

Cortus, B. G., Jeffrey, S. R., Unterschultz, J. R., and Boxall, P. C.: The Economics of Wetland Drainage and Retention in Saskatchewan, Can. J. Agr. Econ., 59, 109-126, https://doi.org/10.1111/j.1744-7976.2010.01193.x, 2011.

Dahl, T. E.: Wetland losses in the United States 1780's to 1980's, US Department of the Interior, Fish and Wildlife Service, Washington DC, 1990.

Dahl, T. E. and Allord, G.: History of Wetlands in the Conterminous Unided States, in National Water Summary on Wetland Resources, United States Geological Survey Water Supply Paper 2425, US Government Printing Office, Reston, Va., 1996.

Daubechies, I.: Ten Lectures on Wavelets, 61, available at: http: //epubs.siam.org/doi/book/10.1137/1.9781611970104 (last access: 22 April 2016), 1992.

David, M. B., Drinkwater, L. E., and McIsaac, G. F.: Sources of Nitrate Yields in the Mississippi River Basin, J. Environ. Qual., 39, 1657, https://doi.org/10.2134/jeq2010.0115, 2010.
David, M. M. B., Gentry, L. L. E., Kovacic, D. A., and Smith, K. M. K.: Nitrogen balance in and export from an agricultural watershed, J. Environ. Qual., 26, 1038-1048, https://doi.org/10.2134/jeq1997.00472425002600040015x, 1997.

Day, S. S., Gran, K. B., Belmont, P., and Wawrzyniec, T.: Measuring bluff erosion part 2: Pairing aerial photographs and terrestrial laser scanning to create a watershed scale sediment budget, Earth Surf. Proc. Land., 38, 1068-1082, https://doi.org/10.1002/esp.3359, 2013.

Dean, W. E. and Schwalb, A.: Holocene Evironmental and Climatic Change in the Northern Great Plains Recorded in the Geochemistry of Sediments in Pickeral Lake, South Dakota, Quaternary Int., 67, 5-20, 2000.

Delong, M. D.: Upper Mississippi River Basin, in Rivers of North America, edited by: Benke, A. C. and Cushing, C. E., Elsevier/Academic Press, Boston, 327-373, 2005.

Diak, G. R., Anderson, M. C., Bland, W. L., Norman, J. M., Mecikalski, J. M., and Aune, R. M.: Agricultural-Management Decision Aids Driven by Real-Time Satellite Data, B. Am. Meteorol. Soc., 79, 1345-1355, https://doi.org/10.1175/15200477(1998)079<1345:AMDADB>2.0.CO;2, 1998.

Dumanski, S., Pomeroy, J. W., and Westbrook, C. J.: Hydrological regime changes in a Canadian Prairie basin, Hydrol. Process., 29, 3893-3904, https://doi.org/10.1002/hyp.10567, 2015.

Fausey, N., Doering, E., and Palmer, M.: Purposes and benefits of drainage, in: Farm Drainage in the United States: History, Status, and Prospects, Miscellaneous Publication No. 1455, edited by: Pavelis, G., US Department of Agriculture, Washington DC, 48$51,1987$.

Feng, S. and $\mathrm{Hu}, \mathrm{Q}$.: Changes in winter snowfall/precipitation ratio in the contiguous United States, J. Geophys. Res., 112(D15), D15109, https://doi.org/10.1029/2007JD008397, 2007.

Foufoula-Georgiou, E., Takbiri, Z., Czuba, J. A., and Schwenk, J.: The change of nature and the nature of change in agricultural landscapes: Hydrologic regime shifts modulate ecological transitions, Water Resour. Res., 51, 6649-6671, https://doi.org/10.1002/2015WR017637, 2015.

Foufoula-Georgiou, E., Belmont, P., Wilcock, P., Gran, K., Finlay, J. C., Kumar, P., Czuba, J. A., Schwenk, J., and Takbiri, Z.: Comment on "Climate and agricultural land use change impacts on streamflow in the upper midwestern United States" by Satish C. Gupta et al., Water Resour. Res., 52, 7536-7539, https://doi.org/10.1002/2015WR018494, 2016.

Fouss, J. L. and Reeve, R. C.: Advances in Drainage Technology: 1955-1985, in Farm Drainage in the United States: History, Status, and Prospects, Miscellaneous Publication No. 1455, edited by: Pavelis, G. A., U.S. Department of Agriculture, Washington D.C., 30-47, 1987.

Frans, C., Istanbulluoglu, E., Mishra, V., Munoz-Arriola, F., and Lettenmaier, D. P.: Are climatic or land cover changes the dominant cause of runoff trends in the Upper Mississippi River Basin?, Geophys. Res. Lett., 40, 1104-1110, https://doi.org/10.1002/grl.50262, 2013.

Fritz, S. C., Ito, E., Yu, Z. C., Laird, K. R., and Engstrom, D. R.: Hydrologic variation in the northern Great Plains during the last two millennia, Quaternary Res., 53, 175-184, https://doi.org/10.1006/qres.1999.2115, 2000. 
Gain, E. W.: Land drainage for production of food and fiber crops, in International Conference on Water for Peace, vol. 7, 451-461, Washington, DC, 1967.

Gerbert, W. A. and Krug, W. R.: Streamflow trends in Wisconsin's Driftless Area, J. Am. Water Resour. As., 32, 733-744, https://doi.org/10.1111/j.1752-1688.1996.tb03470.x, 1996.

Goolsby, D. A., Battaglin, W. A., Lawrence, G. B., Artz, R. S., Aulenbach, B. T., Hooper, R. P., Keeney, D. R., and Stensland, G. J.: Flux and Sources of Nutrients in the Mississippi-Atchafalaya River Basin: Topic 3 Report for the Integrated Assessment on Hypoxia in the Gulf of Mexico, Decision Analysis Series No. 17, NOAA Coastal Ocean Program, Silver Spring, MD, 1999.

Glaser, L.: Inflation-adjusted corn, wheat, and soybean prices, 1912-2014, USDA Econ. Res. Serv., available at: http://www.ers.usda.gov/data-products/chart-gallery/detail. aspx?chartId=40093, last access: 1 January 2016.

Graf, W.: Dam nation: A geographic census of American dams and their large-scale hydrologic impacts, Water Resour. Res., 35, 1305-1311, 1999.

Gran, K. B., Belmont, P., Day, S. S., Jennings, C., Johnson, A., Perg, L. and Wilcock, P. R.: Geomorphic evolution of the Le Sueur River, Minnesota, USA, and implications for current sediment loading, in: Management and Restoration of Fluvial Systems with Broad Historical Changes and Human Impacts: Geological Society of America Special Paper 451, edited by: James, L. A., Rathburn, S. L., and Whittecar, G. R., 119-130, 2009.

Gran, K. B., Belmont, P., Day, S. S., Finnegan, N., Jennings, C., Lauer, J. W., and Wilcock, P. R.: Landscape evolution in south-central Minnesota and the role of geomorphic history on modern erosional processes, GSA Today, 21, 7-9, https://doi.org/10.1130/G121A.1, 2011.

Groisman, P. Y., Knight, R. W., and Karl, T. R.: Heavy precipitation and high streamflow in the contiguous United States: Trends in the twentieth century, B. Am. Meteorol. Soc., 82, 219-246, https://doi.org/10.1175/15200477(2001)082<0219:HPAHSI>2.3.CO;2, 2001.

Groschen, G. E., Harris, M., King, R., Terrio, P., and Warner, K.: Water quality in the lower Illinois River Basin, Illinois, 1995-98, U.S. Geol. Surv. Circ., 1209, 2000.

Guanter, L., Zhang, Y., Jung, M., Joiner, J., Voigt, M., Berry, J. A., Frankenberg, C., Huete, A. R., Zarco-Tejada, P., Lee, J.-E., Moran, M. S., Ponce-Campos, G., Beer, C., CampsValls, G., Buchmann, N., Gianelle, D., Klumpp, K., Cescatti, A., Baker, J. M., and Griffis, T. J.: Global and timeresolved monitoring of crop photosynthesis with chlorophyll fluorescence, P. Natl. Acad. Sci. USA, 111, E1327-E1333, https://doi.org/10.1073/pnas.1320008111, 2014

Hamilton, S. K., Hussain, M. Z., Bhardwaj, A. K., Basso, B., and Robertson, G. P.: Comparative water use by maize, perennial crops, restored prairie, and poplar trees in the US Midwest, Environ. Res. Lett., 10, 64015, https://doi.org/10.1088/17489326/10/6/064015, 2015.

Harrigan, S., Murphy, C., Hall, J., Wilby, R. L., and Sweeney, J.: Attribution of detected changes in streamflow using multiple working hypotheses, Hydrol. Earth Syst. Sci., 18, 1935-1952, https://doi.org/10.5194/hess-18-1935-2014, 2014.

Hartemink, A. E., Lowery, B., and Wacker, C.: Soil maps of Wisconsin, Geoderma, 189-190, 451-461, https://doi.org/10.1016/j.geoderma.2012.05.025, 2012.
Healy, R., Winter, T., LaBaugh, J., and Franke, L.: Water Budgets: Foundations for Effective Water-Resources and Environmental Management, U.S. Geological Survey Circular 1308, 90 pp., available at: http://pubs.er.usgs.gov/publication/cir1308 (last access: 19 September 2017), 2007.

Hewes, L. and Frandson, P. E.: Occupying the Wet Prairie?: The Role of Artificial Drainage in Story County, Iowa, Ann. Assoc. Am. Geogr., 42, 24-50, 1952.

Hickman, G. C., Vanloocke, A., Dohleman, F. G., and Bernacchi, C. J.: A comparison of canopy evapotranspiration for maize and two perennial grasses identified as potential bioenergy crops, GCB Bioenergy, 2, 157-168, https://doi.org/10.1111/j.17571707.2010.01050.x, 2010.

Higgins, R. W. and Kousky, V. E.: Changes in Observed Daily Precipitation over the United States Between 1950 1979 and 1980-2009, J. Hydrometeorol., 120822104745000, https://doi.org/10.1175/JHM-D-12-062.1, 2012.

Hillel, D.: Groundwater drainage and pollution, in: Environmental Soil Physics, Academic Press, San Diego, CA, 471-505, 1998.

Hyden, J.: Wisconsin Dams, Univ. Wisconsin - Milwaukee, available at: http://uwmmap.com/dams.html (last access: 9 June 2016), 2010.

Irwin, R. W. and Whiteley, H. R.: Effects of land drainage on stream flow, Can. Water Resour. J., 8, 88-103, https://doi.org/10.4296/cwrj0802088, 1983.

Johnston, C. A.: Wetland losses due to row crop expansion in the dakota prairie pothole region, Wetlands, 33, 175-182, https://doi.org/10.1007/s13157-012-0365-x, 2013.

Juckem, P. F., Hunt, R. J., Anderson, M. P., and Robertson, D. M.: Effects of climate and land management change on streamflow in the driftless area of Wisconsin, J. Hydrol., 355, 123-130, https://doi.org/10.1016/j.jhydrol.2008.03.010, 2008.

Kibria, K., Ahiablame, L., Hay, C., and Djira, G.: Streamflow Trends and Responses to Climate Variability and Land Cover Change in South Dakota, Hydrology, 3, https://doi.org/10.3390/hydrology3010002, 2016.

Kottek, M., Grieser, J., Beck, C., Rudolf, B., and Rubel, F.: World Map of the Köppen-Geiger climate classification updated, Meteorol. Z., 15, 259-263, https://doi.org/10.1127/09412948/2006/0130, 2006.

Kreiling, R. M. and Houser, J. N.: Long-term decreases in phosphorus and suspended solids, but not nitrogen, in six upper Mississippi River tributaries, 1991-2014, Environ. Monit. Assess., 188, 1-19, https://doi.org/10.1007/s10661-016-5464-3, 2016.

Kronvang, B., Andersen, H. E., Larsen, S. E., and Audet, J.: Importance of bank erosion for sediment input, storage and export at the catchment scale, J. Soils Sediments, 13, 230-241, https://doi.org/10.1007/s11368-012-0597-7, 2013.

Labat, D., Ababou, R., and Mangin, A.: Introduction of Wavelet Analyses to Rainfall/Runoffs Relationship for a Karstic Basin: The Case of Licq-Atherey Karstic System (France), Ground Water, 39, 605-615, https://doi.org/10.1111/j.17456584.2001.tb02348.x, 2001.

Lauer, J. W., Echterling, C., Lenhart, C., Belmont, P., and Rausch, R.: Air-photo based change in channel width in the Minnesota River basin: Modes of adjustment and implications for sediment budget, Geomorphology, https://doi.org/10.1016/j.geomorph.2017.09.005, in press, 2017. 
Lenhart, C., Titov, M., Ulrich, J., Nieber, J., and Suppes, B.: The role of hydrologic alteration and riparian vegetation dynamics in channel evolution along the lower Minnesota River, T. Am. Soc. Agric. Biol. Eng., 56, 549-561, 2013.

Lenhart, C. F., Peterson, H., and Nieber, J.: Increased Streamflow in Agricultural Watersheds of the Midwest: Implications for Management, Watershed Sci. Bull., 2, 25-31, 2011.

Lenhart, C. F., Verry, E. S., Brooks, K. N., and Magner, J. A.: Adjustment of prairie pothole streams to land-use, drainage and climate changes and consequences for turbidity impairment, River Res. Appl., 28, 1609-1619, https://doi.org/10.1002/rra.1549, 2012.

Letey, J., Blair, J. W., Devitt, D., Lund, L. J., and Nash, P.: NitrateNitrogen in Effluent from Agricultural Tile Drains in California, Hilgardia, 45, 289-319, 1977.

Lian, Y., You, J.-Y., Sparks, R., and Demissie, M.: Impact of Human Activities to Hydrologic Alterations on the Illinois River, J. Hydrol. Eng., 17, 537-546, https://doi.org/10.1061/(ASCE)HE, 2012.

Liu, R. Q., Jacobi, C., Hoffmann, P., Stober, G., and Merzlyakov, E. G.: A piecewise linear model for detecting climatic trends and their structural changes with application to mesosphere/lower thermosphere winds over Collm, Germany, J. Geophys. Res., 115, D22105, https://doi.org/10.1029/2010JD014080, 2010.

Livneh, B., Rosenberg, E. A., Lin, C., Nijssen, B., Mishra, V., Andreadis, K. M., Maurer, E. P., and Lettenmaier, D. P.: A LongTerm Hydrologically Based Dataset of Land Surface Fluxes and States for the Conterminous United States: Update and Extensions, J. Climate, 26, 9384-9392, 2013.

Magner, J. A., Payne, G. A., and Steffen, L. J.: Drainage effects on stream nitrate-n and hydrology in south-central Minnesota (USA), Environ. Monit. Assess., 91, 183-198, 2004.

Marschner, F.: The original vegetation of Minnesota, a map compiled in 1930 by F. J. Marschner under the direction of M. L. Heinselman of the United States Forest Service, scale 1:500,000, 1974.

Martin, L.: The Physical Geography of Wisconsin, Third, The University of Wisconsin Press, Madison, WI, 1965.

Maurer, E. P., Wood, A. W., Adam, J. C., Lettenmaier, D. P., and Nijssen, B.: A Long-Term Hydrologically Based Dataset of Land Surface Fluxes and States for the Conterminous United States, J. Climate, 15, 3237-3251, https://doi.org/10.1175/15200442(2002)015<3237:ALTHBD>2.0.CO;2, 2002.

McCorvie, M. R. and Lant, C. L.: Drainage district formation and the loss of midwestern wetlands, 1850-1930, Agr. Hist., 67, 1339, 1993.

McIsaac, G. F., David, M. B., and Illinois, C. A. M. U.: Miscanthus and switchgrass production in central Illinois: iImpacts on hydrology and inorganic nitrogen leaching, J. Environ. Qual., 39, 1790, https://doi.org/10.2134/jeq2009.0497, 2010.

Meyles, E., Williams, A., Ternan, L., and Dowd, J.: Runoff generation in relation to soil moisture patterns in a small Dartmoor catchment, Southwest England, Hydrol. Process., 17, 251-264, https://doi.org/10.1002/hyp.1122, 2003.

Miller, J. E. and Frink, D. L.: Changes in flood response of the Red River of the North basin, North Dakota-Minnesota, US Geol. Surv. Water-Supply Pap. 2243, 103 pp., 1984.

Mueller, N. D., Butler, E. E., McKinnon, K. A., Rhines, A., Tingley, M., Holbrook, N. M., and Huybers, P.: Cooling of US Midwest summer temperature extremes from cropland intensification, Nature Climate Change, 6, 317-322, https://doi.org/10.1038/nclimate2825, 2015.

Naz, B. S., Ale, S., and Bowling, L. C.: Detecting subsurface drainage systems and estimating drain spacing in intensively managed agricultural landscapes, Agr. Water Manage., 96, 627637, https://doi.org/10.1016/j.agwat.2008.10.002, 2009.

Novotny, E. V. and Stefan, H. G.: Stream flow in Minnesota: Indicator of climate change, J. Hydrol., 334, 319-333, https://doi.org/10.1016/j.jhydrol.2006.10.011, 2007.

O'Connell, E., Ewen, J., O'Donnell, G., and Quinn, P.: Is there a link between agricultural land-use management and flooding?, 11, 96-107, 2007.

Palmer, J. A., Schilling, K. E., Isenhart, T. M., Schultz, R. C., and Tomer, M. D.: Streambank erosion rates and loads within a single watershed: Bridging the gap between temporal and spatial scales, Geomorphology, 209, 66-78, https://doi.org/10.1016/j.geomorph.2013.11.027, 2014.

Penna, D., Tromp-van Meerveld, H. J., Gobbi, A., Borga, M., and Dalla Fontana, G.: The influence of soil moisture on threshold runoff generation processes in an alpine headwater catchment, Hydrol. Earth Syst. Sci., 15, 689-702, https://doi.org/10.5194/hess-15-689-2011, 2011.

PRISM Climate Group: Oregon State University, available at: http: //prism.oregonstate.edu (last access: 19 September 2017), 2004.

Randall, G. W. and Mulla, D. J.: Nitrate Nitrogen in Surface Waters as Influenced by Climatic Conditions and Agricultural Practices, J. Environ. Qual., 30, 337-344, 2001.

R Core Team: R: A language and environment for statistical computing, available at: http://www.r-project.org/ (last access: 19 September 2017), 2013.

Robinson, M.: Impact of improved land drainage on river flows, Oxon, UK, 1990.

Rockström, J., Falkenmark, M., Allan, T., Folke, C., Gordon, L., Jägerskog, A., Kummu, M., Lannerstad, M., Meybeck, M., Molden, D., Postel, S., Savenije, H., Svedin, U., Turton, A., and Varis, O.: The unfolding water drama in the Anthropocene: towards a resilience based perspective on water for global sustainability, Ecohydrology, 7, 1249-1261, https://doi.org/10.1002/eco.1562, 2014.

Rosenberg, D. M., Chambers, P. A., Culp, J. M., Franzin, W. G., Nelson, P. A., Salki, A. G., Stainton, M. P., Bodaly, R. A., and Newbury, R. W.: Nelson and Churchill River Basins, in Rivers of North America, edited by: Benke, A. C. and Cushing, C. E., Elsevier/Academic Press, Boston, 853-901, 2005.

Royer, T. V., David, M. B., and Gentry, L. E.: Timing of Riverine Export of Nitrate and Phosphorus from Agricultural Watersheds in Illinois?: Implications for Reducing Nutrient Loading to the Mississippi River, Environ. Sci. Technol., 40, 4126-4131, 2006.

Schaffrath, K. R., Belmont, P., and Wheaton, J. M.: Landscape-scale geomorphic change detection: Quantifying spatially variable uncertainty and circumventing legacy data issues, Geomorphology, 250, 334-348, https://doi.org/10.1016/j.geomorph.2015.09.020, 2015.

Schilling, K. E. and Libra, R. D.: Increased baseflow in Iowa over the second half of the 20th century, J. Am. Water Resour. As., 39, 851-860, https://doi.org/10.1111/j.17521688.2003.tb04410.x, 2003. 
Schilling, K. E., Kult, K., Wilke, K., Streeter, M., and Vogelgesang, J.: Nitrate reduction in a reconstructed floodplain oxbow fed by tile drainage, Ecol. Eng., 102, 98-107, https://doi.org/10.1016/j.ecoleng.2017.02.006, 2017.

Schottler, S. P., Ulrich, J., Belmont, P., Moore, R., Lauer, J. W., Engstrom, D. R., and Almendinger, J. E.: Twentieth century agricultural drainage creates more erosive rivers, Hydrol. Process., 28, 1951-1961, https://doi.org/10.1002/hyp.9738, 2014.

Seuront, L. and Strutton, P. G.: Handbook of scaling methods in aquatic ecology: measurement, analysis, simulation, CRC Press, Boca Raton, FL, 2003.

Simon, A., Rinaldi, M., and Hadish, G.: Channel evolution in the loess area of the Midwestern United States, in Proceedings of the Sixth Federal Interagency Sedimentation Conference, Las Vegas, Nevada, p. III-86-III-93, Federal Interagency Sedimentation Conference, Reston, VA, 1996.

Sims, J. T., Simard, R. R., and Joern, B. C.: Phosphorus Loss in Agricultural Drainage: Historical Perspective and Current Research, J. Environ. Qual., 27, 277-293, 1998.

Skaggs, R., Gilliam, J., Sheets, T., and Barnes, J.: Effects of agricultural land development on drainage waters in the North Carolina tidewater region, Water Resour. Res. Institute, Rep. No. 159, Univ. North Carolina, Raleigh, 1980.

Skaggs, R., Brevé, M., and Gilliam, J.: Hydrologic and water quality impacts of agricultural drainage, Crit. Rev. Environ. Sci. Technol., 24, 1-32, 1994.

Stark, J. R., Andrews, W. J., Fallon, J. D., Fong, A. L., Goldstein, R. M., Hanson, P. E., Kroening, S. E., and Lee, K. E.: Water-Quality Assessment of Part of the Upper Mississippi River Basin, Minnesota and Wisconsin-Environmental Setting and Study Design, US Geol. Surv. Water-Resources Investig. Rep., 96-4098, 1996.

Stoner, J. D., Lorenz, D. L., Wiche, G. J., and Goldstein, R. M.: Red River of the North Basin, Minnesota, North Dakota, and South Dakota, Water Resour. Bull., 29, 575-615, 1993.

Stout, J. C., Belmont, P., Schottler, S. P., and Willenbring, J. K.: Identifying Sediment Sources and Sinks in the Root River, Southeastern Minnesota, Ann. Assoc. Am. Geogr., 104, 20-39, https://doi.org/10.1080/00045608.2013.843434, 2014.

Sugg, Z.: Assessing U S Farm Drainage?: Can GIS Lead to Better Estimates of Subsurface Drainage Extent?, World Resour. Inst., 1-8, available at: http://pdf.wri.org/assessing_farm_drainage.pdf (last access: 19 September 2017), 2007

Sullivan, M., VanToai, T., Fausey, N., Beuerlein, J., Parkinson, R., and Soboyejo, A.: Crop ecology, production \& management: Evaluating on-farm flooding impacts on soybean, Crop Sci., 41, 93-100, https://doi.org/10.2135/cropsci2001.41193x, 2001.

Tomé, A. R. and Miranda, P. M. A.: Piecewise linear fitting and trend changing points of climate parameters, Geophys. Res. Lett., 31, L02207, https://doi.org/10.1029/2003GL019100, 2004.

Torrence, C. and Compo, G. P.: A Practical Guide to Wavelet Analysis, B. Am. Meteorol. Soc., 79, 61-78, 1998.

Trimble, S. W.: Decreased rates of alluvial sediment storage in the Coon Creek Basin, Wisconsin, 1975-93, Science, 285, 1244 1246, https://doi.org/10.1126/science.285.5431.1244, 1999.

Trimble, S. W. and Crosson, P.: U.S. Soil Erosion Rates: Myth and Reality, Science, 289, 248-250, 2000.

United States Army Corps of Engineers: National Inventory of Dams, available at: http://nid.usace.army.mil (last access: 16 January 2017), 2016.
US Bureau of the Census: Irrigation and drainage: General report and analytical tables and reports for states, with statistic for counties, Volume 7, in Fourteenth Census of the United States Taken in the year 1920, United States Department of Commerce, Government Printing Office, Washington, DC, 1922.

US Bureau of the Census: Drainage of agricultural lands, Volume 4, in Sixteenth Census of the United States: 1940, United States Department of Commerce, Government Printing Office, Washington, DC, 1942.

US Bureau of the Census: Drainage of agricultural lands, Volume 4, in United States Census of Agriculture: 1950, United States Department of Commerce, Government Printing Office, Washington, DC, 1952.

US Bureau of the Census: Drainage of agricultural lands, Volume 4, in United States Census of Agriculture: 1959, United States Department of Commerce, Government Printing Office, Washington, DC, 1961.

US Bureau of the Census: Drainage of agricultural lands, Volume 5, Part 5, in 1978 Census of Agriculture, United States Department of Commerce, Government Printing Office, Washington, DC, 1981.

US Department of Agriculture Bureau of Agricultural Economics Crop Reporting Board: Crop Production Annual Summary, 1949, Washington, DC, 1949.

US Department of Agriculture National Agricultural Statistics Service Agricultural Statistics Board: Crop Production Annual Summary, 1989, Washington, DC, 1990.

US Department of Agriculture National Agricultural Statistics Service: Special tabulation: county-level land drained by tile and ditches, 2012 Census Agric., 2014a.

US Department of Agriculture National Agricultural Statistics Service: Summary and state data, 2012 Census Agric., 1, 2014b.

USDA National Agricultural Statistics Service Cropland Data Layer: Published crop-specific data layer, available at: https: //nassgeodata.gmu.edu/CropScape/ (last accessed: 1 November 2016), 2013.

Vandegrift, T. R. and Stefan, H. G.: Annual stream runoff and climate in Minnesota's river basins, Minneapolis, 2010.

Verbesselt, J., Hyndman, R., Newnham, G., and Culvenor, D.: Detecting trend and seasonal changes in satellite image time series, Remote Sens. Environ., 114, 106-115, https://doi.org/10.1016/j.rse.2009.08.014, 2010.

Vörösmarty, C., Lettenmaier, D., Leveque, C., Meybeck, M., PahlWostl, C., Alcamo, J., Cosgrove, W., Grassl, H., Hoff, H., Kabat, P., Lansigan, F., Lawford, R., and Naiman, R.: Humans transforming the global water system, Eos, Trans. Am. Geophys. Union, 85, 509-514, https://doi.org/10.1029/2004EO480001, 2004.

Wilcock, P.: Identifying sediment sources in the Minnesota River Basin, Minnesota River Sediment Colloq., 16, available at: http://www.pca.state.mn.us/index.php/view-document.html? gid=8099 (last access: 19 September 2017), 2009.

Willett, C. D., Lerch, R. N., Schultz, R. C., Berges, S. A., Peacher, R. D., and Isenhart, T. M.: Streambank erosion in two watersheds of the Central Claypan Region of Missouri, United States, J. Soil Water Conserv., 67, 249-263, https://doi.org/10.2489/jswc.67.4.249, 2012. 
Wolf, R. A. and Market, P. S.: On the impact of corn and soybeans to the local moisture budget in Iowa, Natl. Weather Dig., 31, 3-7, 2007.

Wuebker, E. F., Mullen, R. E., and Koehler, K.: Flooding and temperature effects on soybean germination, Crop Sci., 41, 18571861, https://doi.org/10.2135/cropsci2001.1857, 2001.

Xu, X., Scanlon, B. R., Schilling, K., and Sun, A.: Relative importance of climate and land surface changes on hydrologic changes in the US Midwest since the 1930s: Implications for biofuel production, J. Hydrol., 497, 110-120, https://doi.org/10.1016/j.jhydrol.2013.05.041, 2013.

Zeileis, A., Kleiber, C., Krämer, W., and Hornik, K.: Testing and dating of structural changes in practice, Comput. Stat. Data An., 44, 109-123, https://doi.org/10.1016/S0167-9473(03)00030-6, 2003.
Zeri, M., Hussain, M. Z., Anderson-Teixeira, K. J., Delucia, E., and Bernacchi, C. J.: Water use efficiency of perennial and annual bioenergy crops in central Illinois, J. Geophys. Res.-Biogeo., 118, 581-589, https://doi.org/10.1002/jgrg.20052, 2013.

Zhang, Y. K. and Schilling, K. E.: Increasing streamflow and baseflow in Mississippi River since the 1940s: Effect of land use change, J. Hydrol., 324, 412-422, https://doi.org/10.1016/j.jhydrol.2005.09.033, 2006. 